Bull. Fac. Agric., Cairo Univ.,70:1-18 (2019).

\title{
A STUDY OF SOME DEMOGRAPHIC, SOCI-ECONOMIC ASPECTS OF WOMEN IN THE RURAL AND URBAN AREAS OF ASSIUT GOVERNORATE
}

(Received:16. 2. 2019)

\author{
By \\ Randa Y. M. Sultan and *Samia A. Helal \\ Department of Rural Sociology and * Department of Agriculture Extension, \\ Faculty of Agriculture, Assiut University, Egypt.
}

\begin{abstract}
Women's issues in the Arab Republic of Egypt lately witness a great interest and a strong belief in the important role they play in community development. However, rural women suffer various types of retardation and lack of education, health or living services although they play many important roles that drive the rural developmental process. Despite numerous attempts by the government to improve women's conditions in society, rural women's conditions had no impact because all programs for women benefit urban women rather than rural women, who suffer social isolation. Therefore, the present research aimed to study some of the Demographic, Soci-economic and living aspects of both rural and urban women in Assiut Governorate, as well as identify the differences between women in rural and urban areas in the these aspects. In order to achieve this, the research relied on two types of data, mamely secondary data from the 2017 census and preliminary data, which have been collected through a questionnaire prepared for this purpose. Five centers were randomly selected and the city was chosen as urban. Each village was randomly chosen to represent the rurals, The data were collected from a sample of 250 families from each of the selected cities and villages. The data from the recent census of 2017 showed that there were some differences between rural and urban women in some social, demographic and economic aspects. The data collected from the study sample revealed differences in many demographic aspects such as age of marriage, preferred age of marriage for males, preferred age of marriage for females, number of births, number of children desired, and the use of family planning methods. Social aspects included marriage, decision making, community participation, openness to the outside world, educational aspects such as preference for educating children rather than learning a craft, the importance of educating girls. Health aspects included attending to a doctor during pregnancy, continuing to vaccinate children, using home remedies, economic aspects included having a bank account, having an insurance policy, preference for private employment, and participation in household expenses. Living conditions included the dwelling being healthy, certain characteristics of the dwelling, agricultural aspects such as land ownership, poultry farming and animal husbandry.
\end{abstract}

Keywords: rural and urban women, demographic, social and economic aspects.

$$
\begin{aligned}
& \text { دراسة لبعض النواحى الايموجرافية والاجتماعية والاقتصادية للمرأة بريف وحضر محافظة أسيوط } \\
& \text { رندا يوسف محمد سلطان - سامية عبد السميع هلال } \\
& \text { قسم الاجتماع الريفى و* قسم الارشاد الزر اعى ـ كلية الزر اعة - جامعة اسيوط ـ مصر. }
\end{aligned}
$$

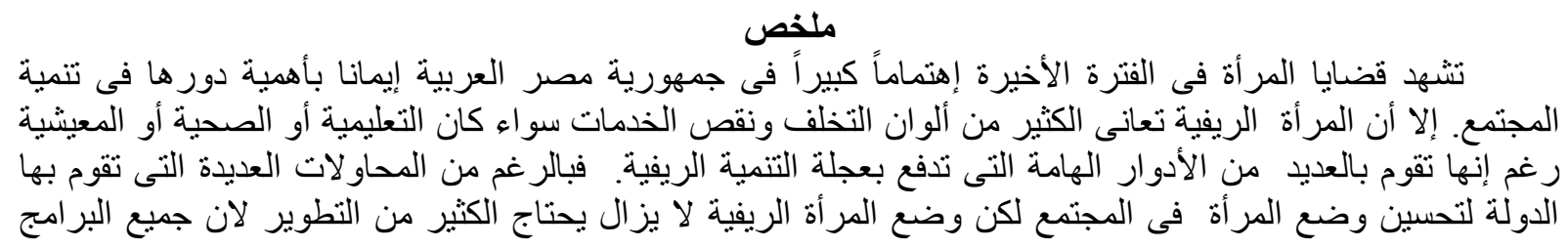


المخصصة للمر أة كان المستفيد منها هو المرأة الحضرية أكثر من الريفية. فالمرأة الريفية تعانى من العزلة العالية الاجتماعية.

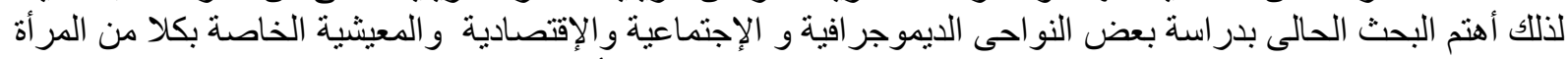

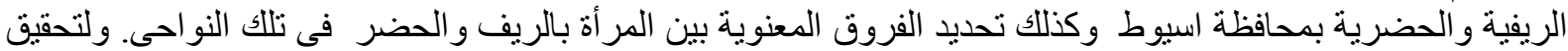

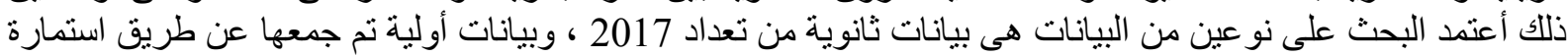

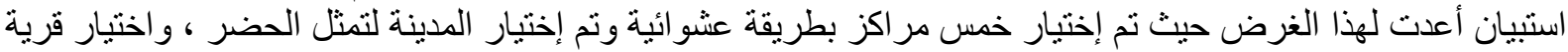

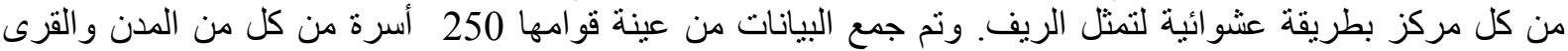

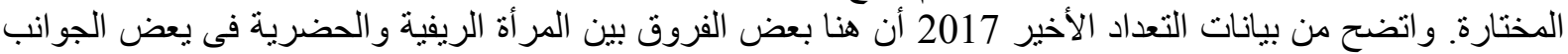

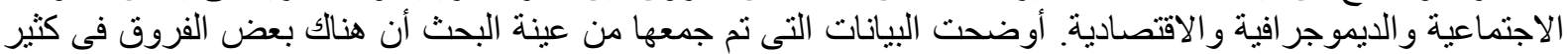

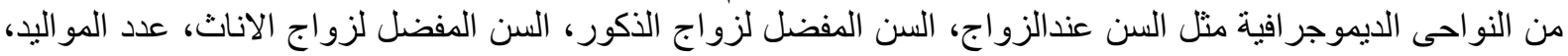

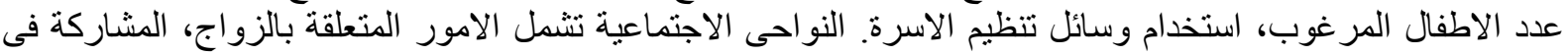

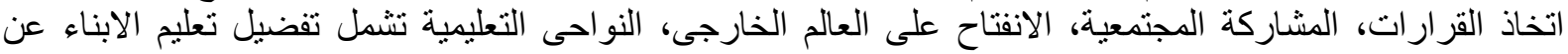

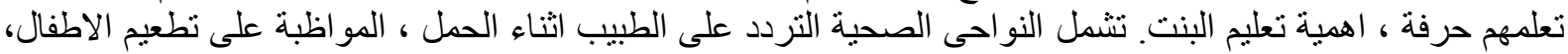

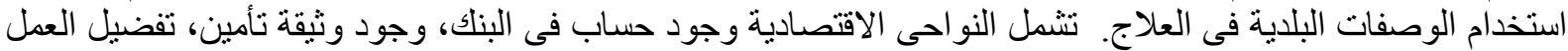

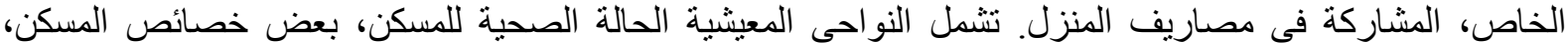
النواحى الزر اعية مثل ملكية الارض ، تربية الدواجن وتربية الحيو انات .

\section{3شكلة البحث الاثرة}

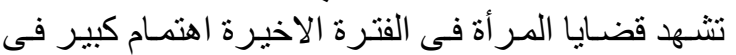

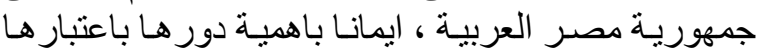

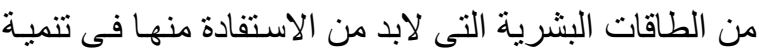

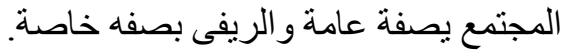

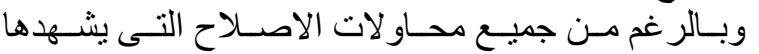

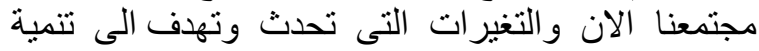

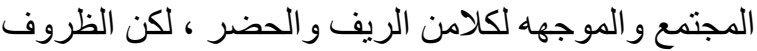

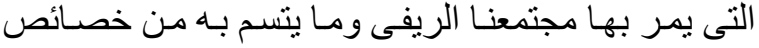

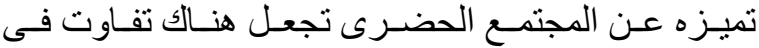

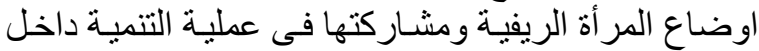

الإجتمع ، الامر الذى انعكس على دور ها ونشاطها.

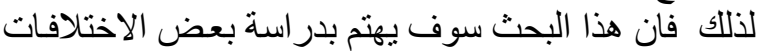
الاجتماعسية والاقتصادية و الديموجر افية بين المر أة الريفية

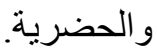

\section{4. - أهداف البحث}

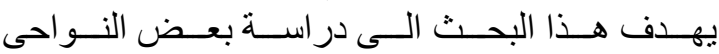

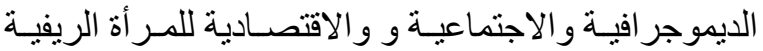

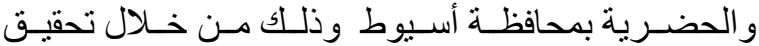
الاهداف الفر عية الاتية :-

1- در اسـة لبعض الخص الخصـائص للمـر أة الريفيـة و الحضـرية

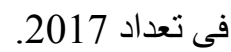

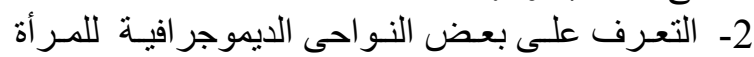
الريفية والحضرية بمحافظة اسيوط.

3- التعرف على بعض النوافية واحى الاجتماعية للمر أة الريفية

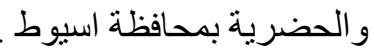

4- التعرف على بعض بعض النواحي التعليميـة للمر أة الريفيـة و الحضرية بمحافظة اسيوط.

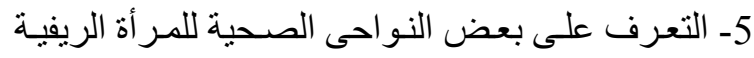

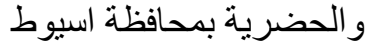

6- التعرف على بعض النواحى الاقتصادية للمر أة الريفيـة

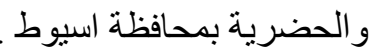

7- التعرف على بعض النواحى المعيشية للمر أة الريفية

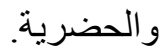

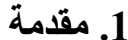

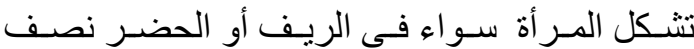

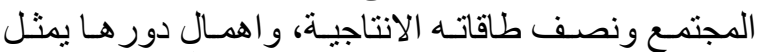

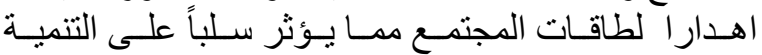

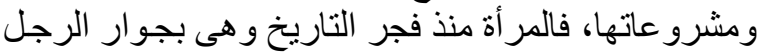

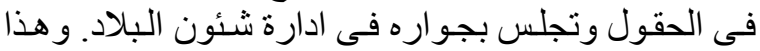

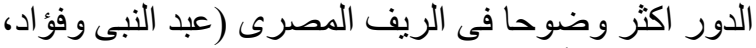
1999). فالمر أة الريفية مورد بشرى مهم وكبير لو الرئ احسن الرون

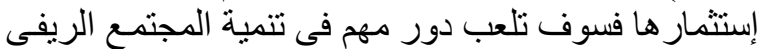
( على، 1993). لكن و اقع المر أة الريفية فى الدول النقامية النامية

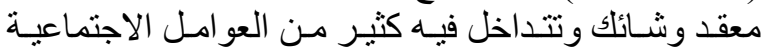

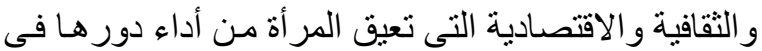

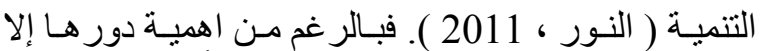

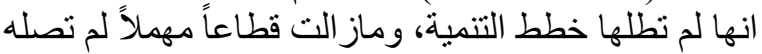

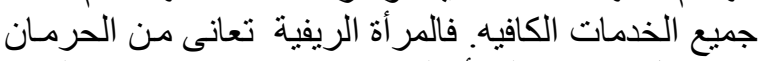

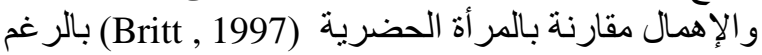

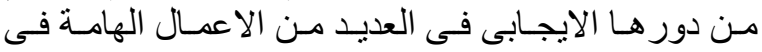

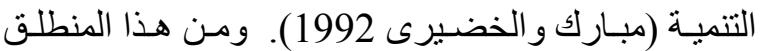
يهتم هذا البحثث بدر اسـة الاختلافـات بـين المـر أة الريفيـة

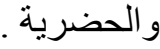

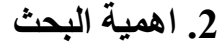

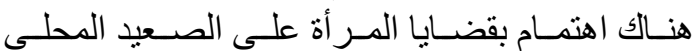

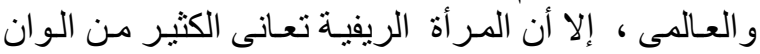

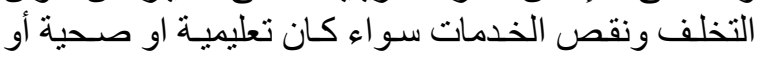

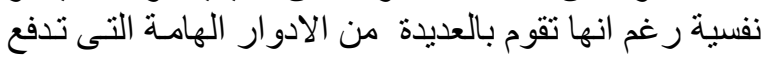

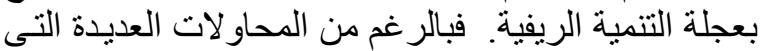

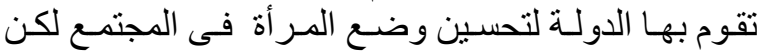

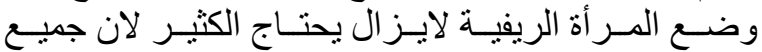

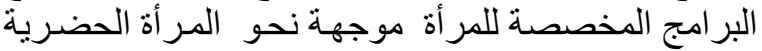

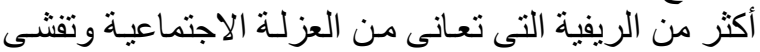

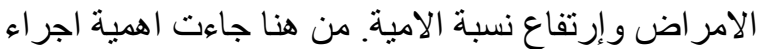

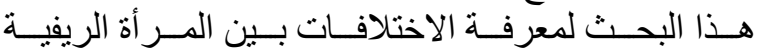
و الحضرية فى محافظة أسيوط. 


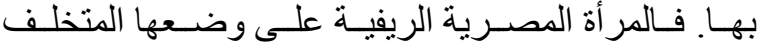

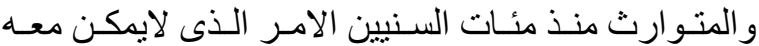

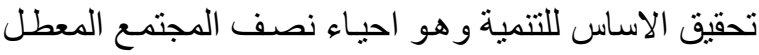

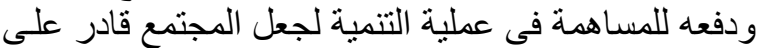
مو اجهة تحديات العصر (الساعاتى، 2006).

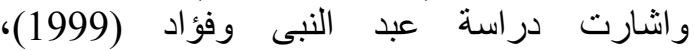
Butt et al.2010) النور(2011)، الحمبرى(2002) (12011)

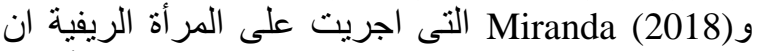

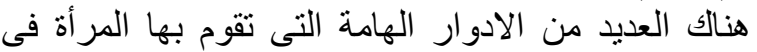

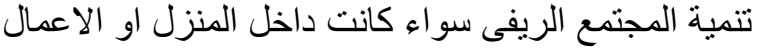
الزراعية. كما ذكرت در اسات كل من حجازى (2008)، (1993)،

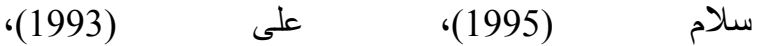
‘FAO(2017) ‘Akbay and Ababakr (2018) Kongolo and bamgose (2002) المعوقات التى تحول دون المشاركة الفعالة للمرأة في في

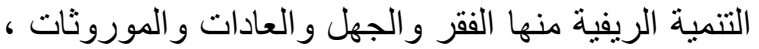

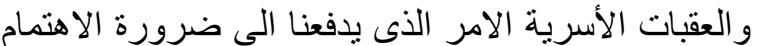

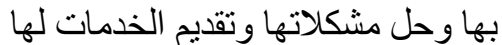

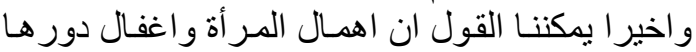

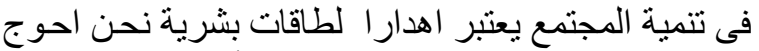

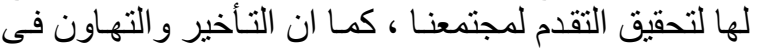

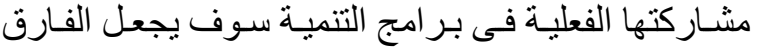
كبير بينها وبين الرجل مما يعرقل مشرو برات التهات التنمية.

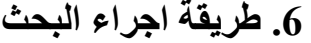 \\ لأجراء هذا البحث تم إتباع الخطوات الاتهية

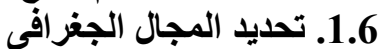

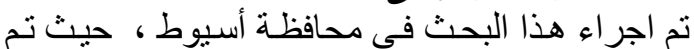

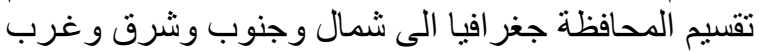

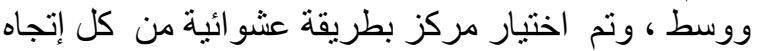
من الإتجاهات المحددة فأسفرت عملية الإختيار عن مركز

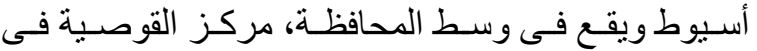

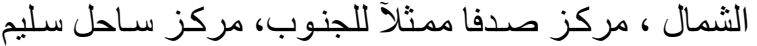

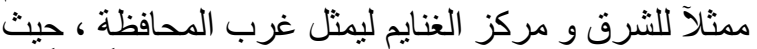

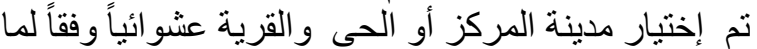

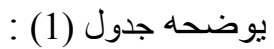

جدول (1): بيان المراكزوفقاً لموقعها بالمحافظة والاحياء الممثلة لها وكذلكت القرى بكل منها.

\begin{tabular}{|c|c|c|c|}
\hline القرية & المدينة/ حى & الاتجاه & المركز \\
\hline او لاد رايق & البيسرى & الوسط & اسبوط \\
\hline عiلك & القوصية & الشمال & القوصية \\
\hline الو عاضلة & صدفا & الجنوب & صدفا \\
\hline الخو الد & ساحل سليم & الثرق & ساحل سليم \\
\hline العامرى & الغنايم & غرب & الغنايم \\
\hline
\end{tabular}

2.6. تحديد المجال البشرى

تم تحديد عدد الاسر فى المدن والقرى القرى المختارة طبقا لتعداد 2006 نظر العدم تو افر عدد الأسر في تعداد 2016

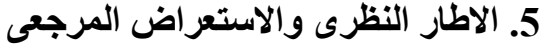

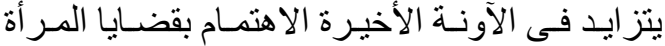

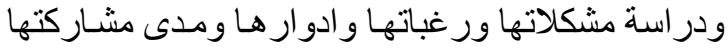

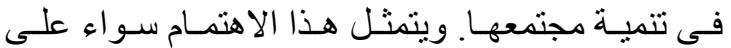

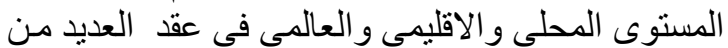

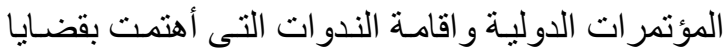

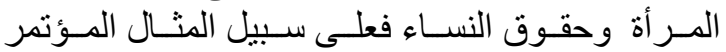

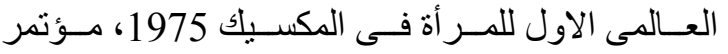

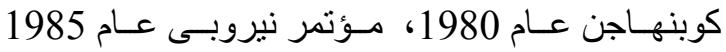
مؤتمر البيئة والتنمية عام 1992 ، مؤتمرر فيينـا 1993

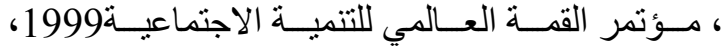

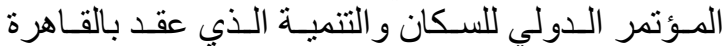

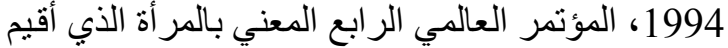

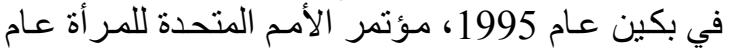

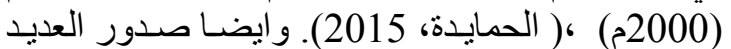

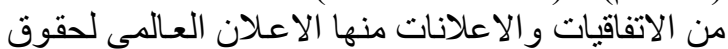

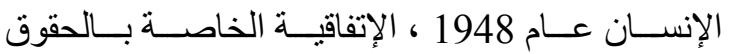

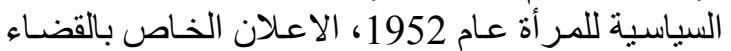

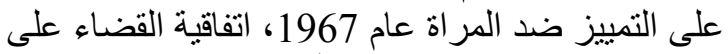
1979 جميع اشكال التمييز ضد المر أة (CEDAW)

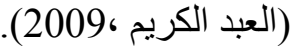

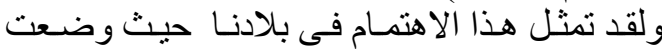

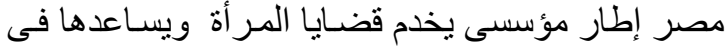

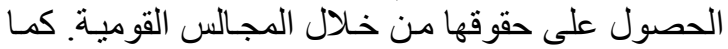

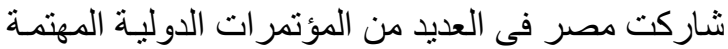

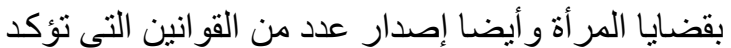

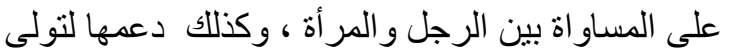
مناصب قيادية وخوض الانتخابات بجوار الرجل الرجل (سالم،

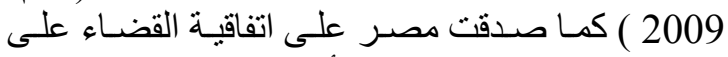

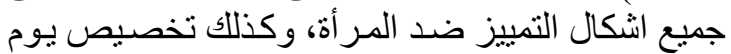

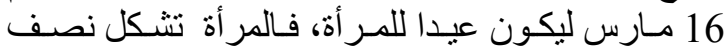

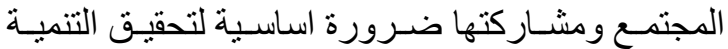

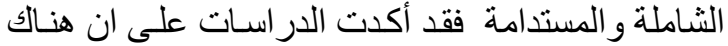

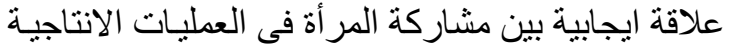

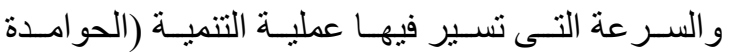
و الطاهات،2017) .

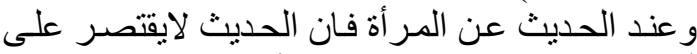

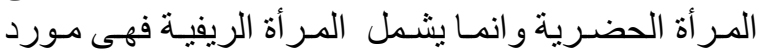

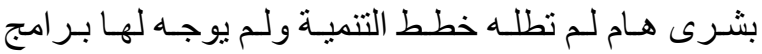

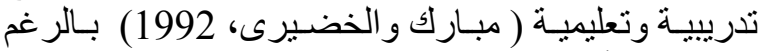

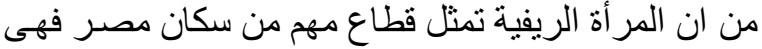

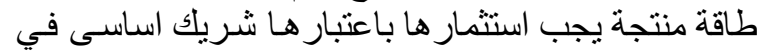

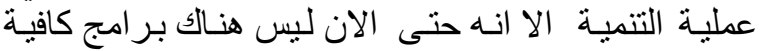

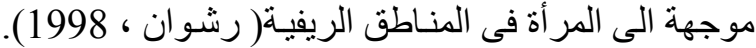

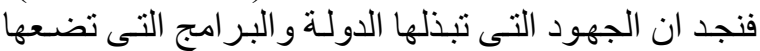

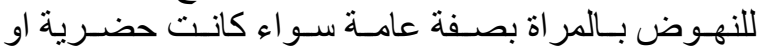

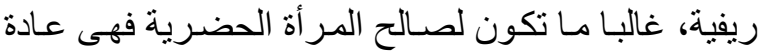

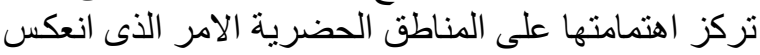

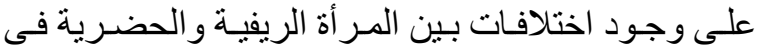

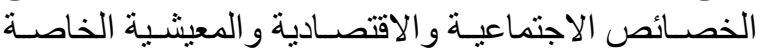


الأميات (50.0\%)، ومن تقرأ وتكتب (12,4\%)

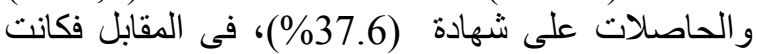
نسبة الأميات الحضريات (10.4\%)، وكانات (37\%)، فيلت نسبة من

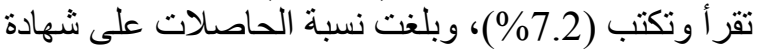

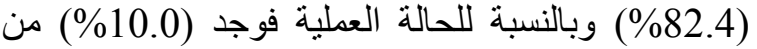
الريفيات تعملن مقابل (68,0\%) من الحضريات.
المنشور فى 2017 وتم اختيار عينة حجمها 250 اسرة من البنات

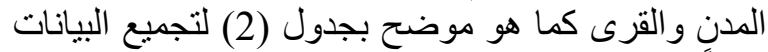

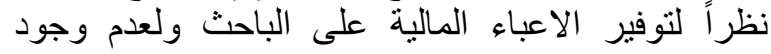
ميزانية مخصصة للبحث العلمى، وايضا لباء قيام الباحث بتجميع البيانات بنفساه.

جدول (2) : حجم الثاملة والعينة بمدن وقرى الدراسة .

\begin{tabular}{|c|c|c|c|c|c|c|c|}
\hline العينة & عدد الاسر & القرية & العينة & عدد الاسر & المدينة/حي & الاتجاه & المركز \\
\hline 49 & 787 & او لاد رايق & 19 & 2956 & البيسرى & الوسط & اسيوط \\
\hline 48 & 768 & Slic & 98 & 15312 & القوصية & الشمال & القوصية \\
\hline 44 & 707 & الو عاضلة & 29 & 4526 & صدفا & الجنوب & صدفا \\
\hline 61 & 973 & الخو الد & 43 & 6689 & ساحل سليم & الشرق & ساحل سليم \\
\hline 48 & 777 & العامرى & 61 & 9526 & الغنايم & غرب & الغنايم \\
\hline 250 & 4012 & & 250 & 39009 & & & الاجمالى \\
\hline
\end{tabular}

جدول (3): التوزيع العددى و النسبى للخصائص الثخصية الاجتماعية والاقتصادية لعينة البحث.

\begin{tabular}{|c|c|c|c|c|}
\hline \multicolumn{2}{|c|}{ حضر } & \multicolumn{2}{|c|}{ ريف } & البيان \\
\hline$\%$ & عدد & $\%$ & عدد & \\
\hline 100 & 250 & 100 & 250 & لمبحوثات \\
\hline & & & & لسن \\
\hline 18.0 & $\begin{array}{c}45 \\
143\end{array}$ & $\begin{array}{l}32.8 \\
500\end{array}$ & $\begin{array}{c}82 \\
125\end{array}$ & $\begin{array}{l}-20 \\
-30\end{array}$ \\
\hline 248 & 62 & 172 & 43 & +40 \\
\hline & & & & الحالـــا \\
\hline 10.4 & 26 & 50.0 & 125 & مية \\
\hline 7.2 & 18 & 12.4 & 31 & ققر أ وتكتب \\
\hline 18.0 & 45 & 14.8 & 37 & بتدائى \\
\hline 8.8 & 22 & 11.2 & 28 & عدادى \\
\hline 26.0 & 65 & 6.0 & 15 & كانوى . \\
\hline 29.6 & 74 & 5.6 & 14 & جامعى فأكثر \\
\hline & & & & لحالــــــــــة \\
\hline 68.0 & 170 & 10.0 & 25 & تعل \\
\hline 32.0 & 80 & 90.0 & 225 & لا تعمل \\
\hline
\end{tabular}

\section{0. النتائج ومناقشتها}

سوف نتناول فى هذا الجزء وضنع المر أة الريفية

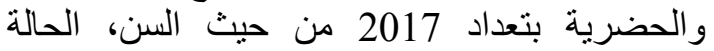
التعليمية، اسباب التسرب من التعليم، الحالة الزواجية،

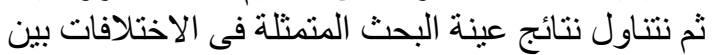

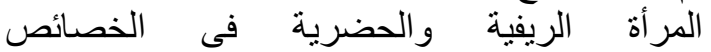

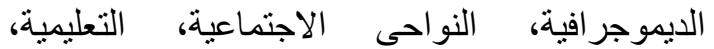
الصحية، الاقتصادية و المعيشية و الزر اعية.
3.6.أداة جمع البيانات

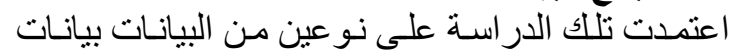

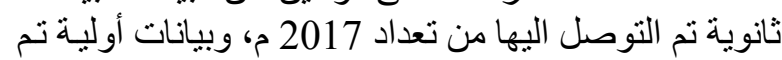

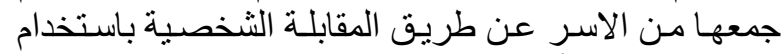

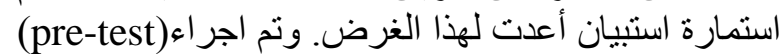

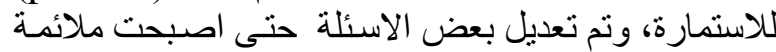

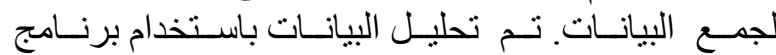

. (SPSS)

\section{7. الأساليب الاحصائية المستخدمة}

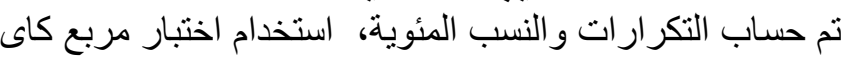

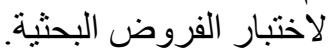

\section{8. فروض البحث الرئو}

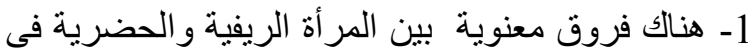

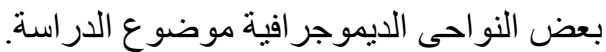

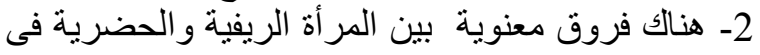

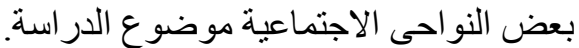

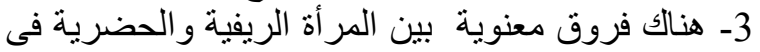

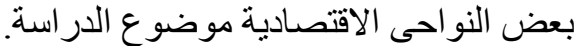

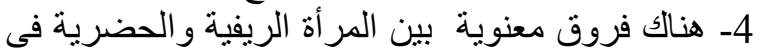

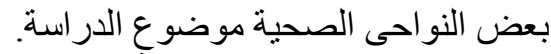

\section{9. وصف عينة البحث البثة}

يوضح جدول رقم (3) التوزيع العددى و النسبى لبعض البحض

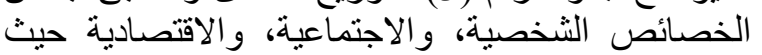

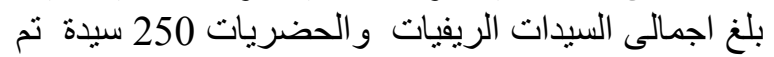
جمع البيانات منهن، بالنسبة للسن بلغت نسبة الريفيات التى التى

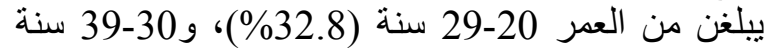

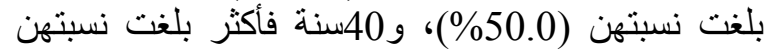
(17.2\%)، فى المقابل بلغت نسبة الحضريات البالغات من العمر 20-29 سنة (18.0\%)، والفة)، و30-39 سنة بلغت نسبتهن (57.2\%)، و40سنة فاكثر بلغت (29) نسبتهن (24.8\%). بالنسبة للحالة التعليمية بلغت نسبة الريفيات 


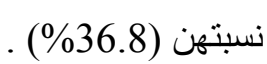

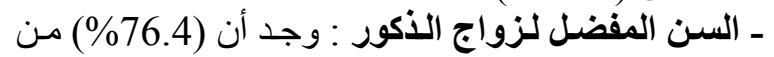

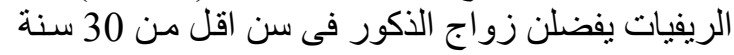

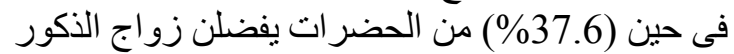

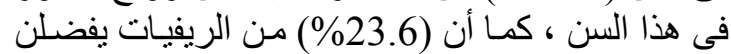

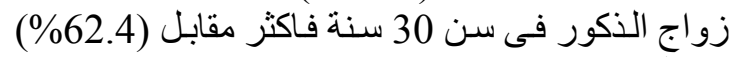

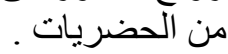

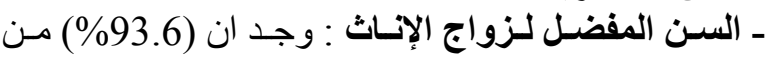

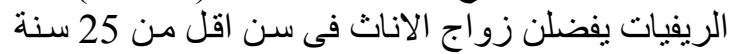

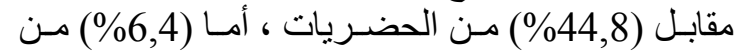

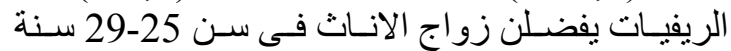

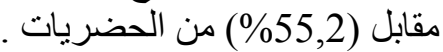

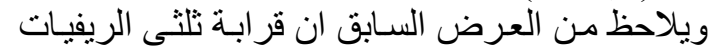

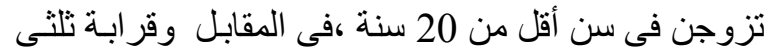

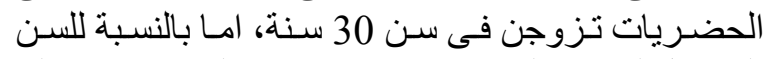

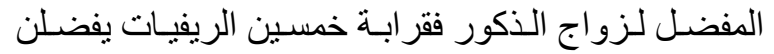

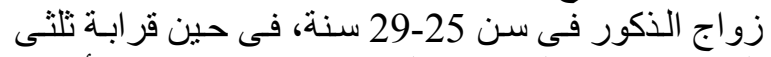

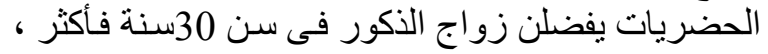

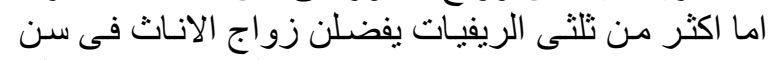

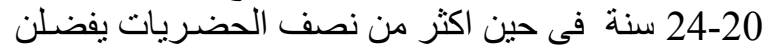
زواج الاناث فى سن 25-25-20 سنة

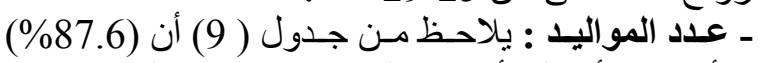

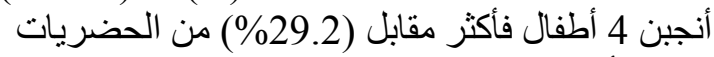

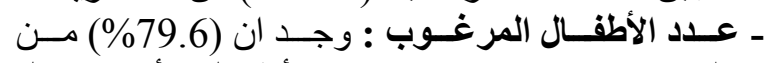

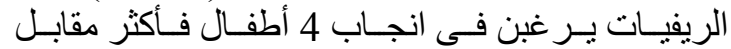
(22.8\%) من الحضريات.
1.10. وضع المراة الريفية والحضرية بتعداد 2017 اعتمد هذا الجزء على البيانات الثانويـة المنشورة فئه

2017. تعداد اعند 1- السن: يوجد اختلاف بسيط في السن سواء في المرأة

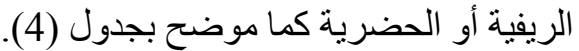

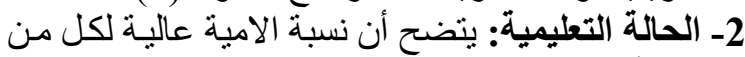

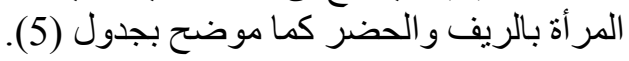
3-اسباب التسرب من التعليم

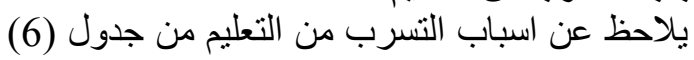

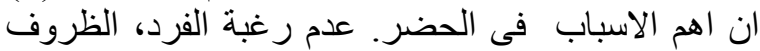

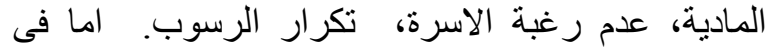

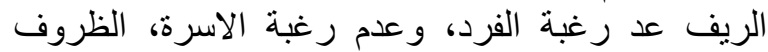

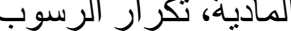
4-الحالة الزواجية (الاجتماعية)

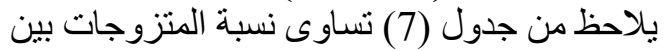
الريفيات و الحضريات حيث بلغت قرئ ابة النصف. 2.10. نتائج عينة البحث 1.2.10. بعض النواحى اللايموجر افية للمراة الريفية والحضرية

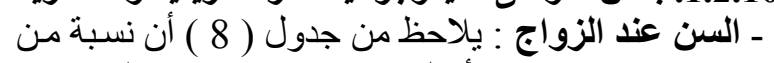

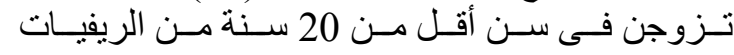

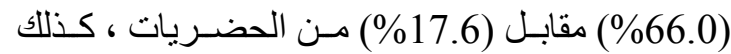

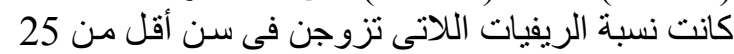

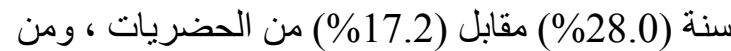

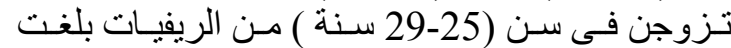

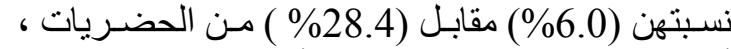

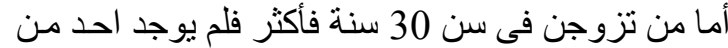

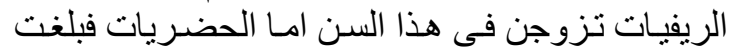

جدول (4) : التوزيع النسبى للمر أة بريف وحضر محافظة اسيوط حسب السن ومحل الاقامة فى تعداد 2017.

\begin{tabular}{|c|c|c|c|c|}
\hline \multicolumn{4}{|c|}{ محل الاقامة } & \multirow[t]{3}{*}{ السن } \\
\hline \multicolumn{2}{|c|}{ ريف } & \multicolumn{2}{|c|}{ حضر } & \\
\hline$\%$ & عدد & $\%$ & عدد & \\
\hline 3.1 & 101.330 & 3.2 & 37.235 & اقل من سنة \\
\hline 11.5 & 375.016 & 9.3 & 106.167 & -1 \\
\hline 12.5 & 406.407 & 10.8 & 123.350 & -5 \\
\hline 10.8 & 352.366 & 9.4 & 108.016 & -10 \\
\hline 10.8 & 350.838 & 10.2 & 116,389 & -15 \\
\hline 9.3 & 300.865 & 9.4 & 107.660 & -20 \\
\hline 8.7 & 281.830 & 9.1 & 102.846 & -25 \\
\hline 7.0 & 224.534 & 7.6 & 86.562 & -30 \\
\hline 5.9 & 192.937 & 6.3 & 71.941 & -35 \\
\hline 4.5 & 147.261 & 5.2 & 58.678 & -40 \\
\hline 4.0 & 126.959 & 4.5 & 51.025 & -45 \\
\hline 3.4 & 110.852 & 4.1 & 46,496 & -50 \\
\hline 2.7 & 90,202 & 3.5 & 39.282 & -55 \\
\hline 2.3 & 73.813 & 2.9 & 33.337 & -60 \\
\hline 1,5 & 48.588 & 1.9 & 21.281 & -65 \\
\hline 1.0 & 32.019 & 1.1 & 12.864 & -70 \\
\hline 0.5 & 15.575 & 1.0 & 6.114 & -75 \\
\hline 0.3 & 10.424 & 0.3 & 3.553 & -80 \\
\hline 0.1 & 4.160 & 0.1 & 1.492 & -85 \\
\hline 0.1 & 2,249 & 0.1 & 776 & +90 \\
\hline 100.0 & 3248225 & 100.0 & 1135064 & الجملة \\
\hline
\end{tabular}


جددول (5): التوزيع النسبى للمرأة بريف وحضر محافظة اسيوط حسب الحالة التعليمية ومحل الاقامة فى تعداد 2017.

\begin{tabular}{|c|c|c|c|c|}
\hline \multicolumn{4}{|c|}{ محل الاقامة } & \multirow[t]{2}{*}{ الحالة التعليمية } \\
\hline \multicolumn{2}{|c|}{ ريف } & \multicolumn{2}{|c|}{ حضر } & \\
\hline$\%$ & عدد & $\%$ & عدد & \\
\hline 39.7 & 939.121 & 20.7 & 179.801 & أمسى \\
\hline 10.7 & 252.501 & 8.6 & 75.043 & يقر أ ويكتب بدون مؤ هل \\
\hline 0.5 & 10816 & 0.3 & 2.306 & محو أمبية \\
\hline 0.1 & 3.036 & 0.2 & 2.103 & تزبية فكرية \\
\hline 11.5 & 273.183 & 9.7 & 84.336 & ابتدائية \\
\hline 7.9 & 186,109 & 7.9 & 68.514 & اعدادية \\
\hline 5.1 & 120,423 & 7.7 & 66.795 & ثانوية عامة/ او ازهرية \\
\hline 18.3 & 433.711 & 23.6 & 205.065 & مؤ هل متوسط فنى \\
\hline 1.5 & 35.651 & 4.2 & 36.323 & مؤهل فوق المتوسط \\
\hline 4.5 & 106.750 & 16.3 & 141.234 & مؤ هل جامعىى \\
\hline 0.1 & 2,316 & 0.3 & 2.585 & دبلوم عالى \\
\hline 0.1 & 1.297 & 0.2 & 1.928 & ماجستير \\
\hline 0.02 & 558 & 0.3 & 2.279 & دكتور اه \\
\hline 100.0 & 2365373 & 100.0 & 868312 & الجملة \\
\hline
\end{tabular}

جذول (6): التوزيع النسبى للمر أة بريف وحضر محافظة اسيوط طبقا للسبب الرئيسى للتسرب في تعداد 2017.

\begin{tabular}{|c|c|c|c|c|}
\hline \multicolumn{4}{|c|}{ محل الاقامة } & \multirow[t]{3}{*}{ اسباب التسرب } \\
\hline \multicolumn{2}{|c|}{ ريف } & \multicolumn{2}{|c|}{ حضر } & \\
\hline$\%$ & عدد & $\%$ & عدد & \\
\hline 5.5 & 3.948 & 1.6 & 158 & صعوبة الوصول الى المدرسة \\
\hline 40.2 & 29.108 & 39.6 & 3.945 & عدم رغبة الفرد \\
\hline 18.9 & 13.683 & 16.3 & 1.625 & عدم رغبة الاسرة \\
\hline 16.2 & 11.746 & 18.3 & 1.823 & ظروف مادية \\
\hline 1.2 & 862 & 1.6 & 163 & وفاة احد الو الدين \\
\hline 0.2 & 135 & 0.4 & 35 & انفصال الو الدين \\
\hline 11.9 & 8.673 & 16.5 & 1.641 & تكرار الرسوب \\
\hline 1.4 & 1.008 & 2.2 & 223 & العمل \\
\hline 4.0 & 2.935 & 2.8 & 281 & الزواج \\
\hline 0.5 & 410 & 0.7 & 72 & الاعاقة \\
\hline 100.0 & 72373 & 100.0 & 9966 & الجملة \\
\hline
\end{tabular}

جدول (7): التوزيع النسبى للمر أة بريف وحضر محافظة اسيوط طبقا للحالة الزواجية ومحل الاقامة في تعداد 2017.

\begin{tabular}{|c|c|c|c|c|}
\hline \multicolumn{4}{|c|}{ محل الاقامة } & \multirow{3}{*}{ الحالة الزواجية } \\
\hline \multicolumn{2}{|c|}{ ريف } & \multicolumn{2}{|c|}{ حضر } & \\
\hline$\%$ & عدد & $\%$ & عدد & \\
\hline 24.1 & 436.330 & 29.0 & 201.051 & لم يتزوج \\
\hline 0.2 & 4.258 & 0.5 & 3.561 & عقد قران \\
\hline 69.7 & 1.256 .694 & 63.8 & 441.104 & متزوج \\
\hline 0.6 & 11.436 & 0.8 & 5.220 & مطلق \\
\hline 5.3 & 94.827 & 5.8 & 40.237 & ارمل \\
\hline 100.0 & 1803545 & 100.0 & 691173 & الجملة \\
\hline
\end{tabular}


جدول ( 8): التوزيع العددى والنسبى لافراد عينة البحث بريف وحضر محافظة اسيوط حسب السن عند الزواج وسن الزوج المفضل لكلا من الأكور والاناث.

\begin{tabular}{|c|c|c|c|c|c|c|c|c|c|c|c|c|}
\hline \multicolumn{6}{|c|}{ حضر } & \multicolumn{6}{|c|}{ ريف } & \multirow[t]{3}{*}{ البيان } \\
\hline \multicolumn{2}{|c|}{ لزاواج الاناث } & \multicolumn{2}{|c|}{ لزالين المفضور } & \multicolumn{2}{|c|}{ السن عند الزواج } & \multicolumn{2}{|c|}{ لزواج الاناث } & \multicolumn{2}{|c|}{ لزالئ الذفضور } & \multicolumn{2}{|c|}{ الزواج عند } & \\
\hline$\%$ & عدد & $\%$ & عدد | عل & $\%$ & عدد & $\%$ & عدد & $\%$ & عدد & $\%$ & عدد & \\
\hline- & - & - & - & 17,6 & 44 & 34.4 & 86 & - & - & 66.0 & 165 & اقلّلة منة \\
\hline 44.8 & 112 & - & - & 17.2 & 43 & 59.2 & 148 & 33.6 & 84 & 28.0 & 70 & 24-20 \\
\hline 55.2 & 138 & 37.6 & 94 & 28.4 & 71 & 6.4 & 16 & 42.8 & 107 & 6.0 & 15 & $29-25$ \\
\hline- & - & 62.4 & 156 & 36.8 & 92 & - & - & 23.6 & 59 & - & - & 30 سنة فاكثر \\
\hline 100 & 250 & 100 & 250 & 100 & 250 & 100 & 250 & 100 & 250 & 100 & 250 & الاجمالى \\
\hline
\end{tabular}

(58.4\%) من الريفيات ذكرت انها تؤثر على المستوى (الإن

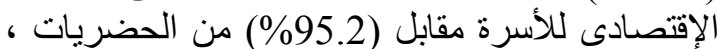

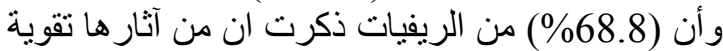

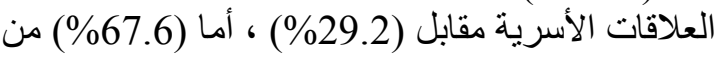

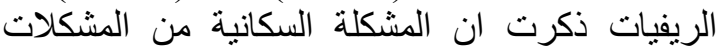
الهامة فى مصر، مقابل (92.0\%) من الإن الحضريات.

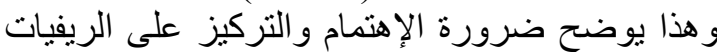

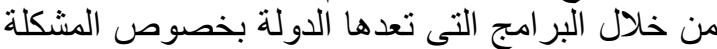

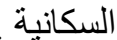

يلاحظ مما سبق ان اكثر من نصف الريفيات اشاروا

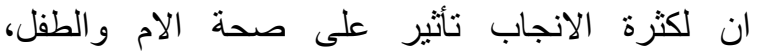

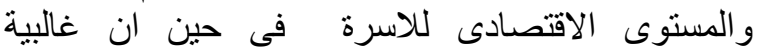

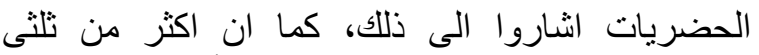

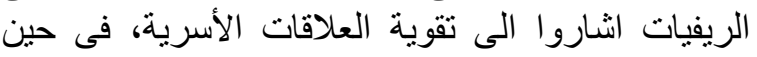

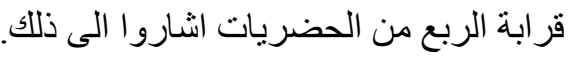

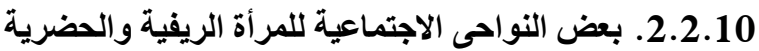

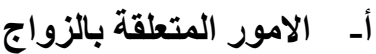

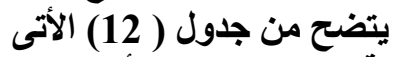

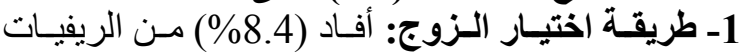

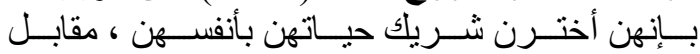

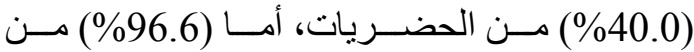
الريفيـات أفـادن بـأن الاختيـار يتت عن طريـق الأهـل مقابل (60,0\%) من الحضريات . 2- صلة القرابة بن الزوجين : ذكر (74.0\%) من

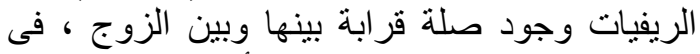
حين (34.0\%) من الحضريات أفادن بوجود صلة الزوجة فينة قر ابة. 3- عدد مرات الزواج : وجد أن (24.0\%) من الريفيات

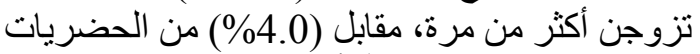

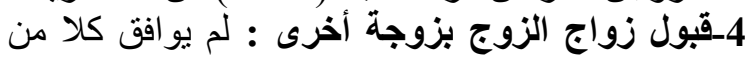

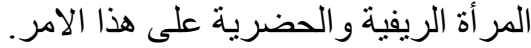
يلاحظ ان الغالبية العظمى من الريفية الريات تم اختيار الزوج عن طريق الاهل فى حين ثلثى الحضريات الثيات الثاروا

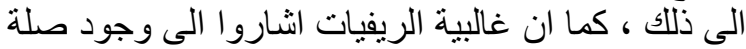
قرابة بينهن وبين الزوج ، الئه الريفات المقابل ثلث الحضرويات

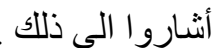

يلاحظ من العرض السابق ان قرابة نصف الريفيات

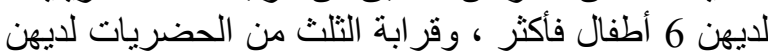

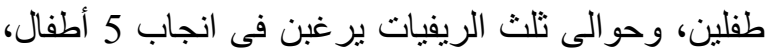

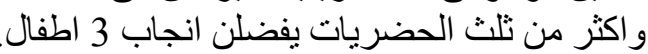

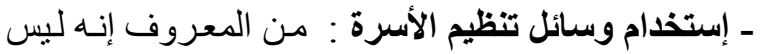

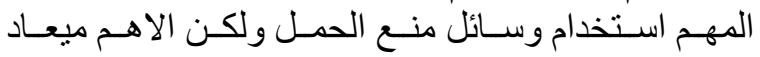

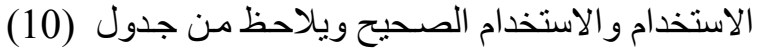

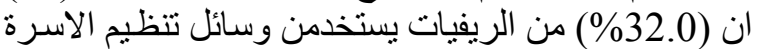

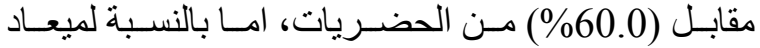

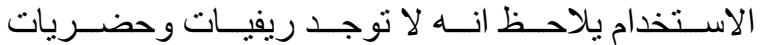

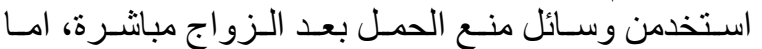

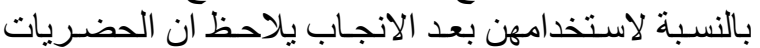

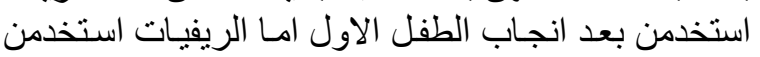

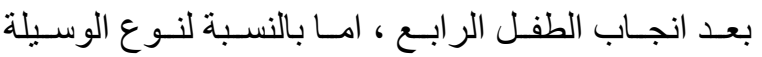

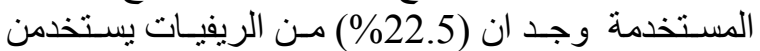

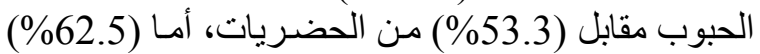

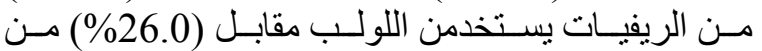

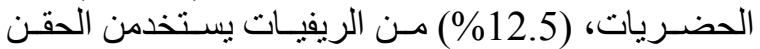

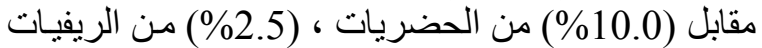
يستخدمن العازل الطبى مقابل (10.7\%) من الحضريات،

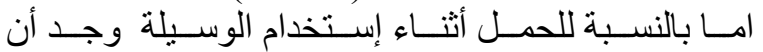

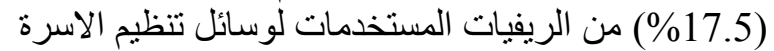
حدث لهن حمل مقابل (13.3\%) من الريفي الحضريات.

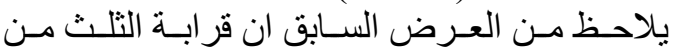

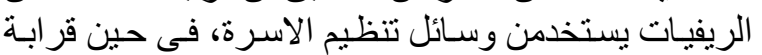

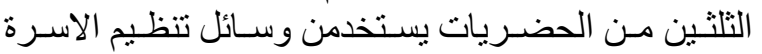

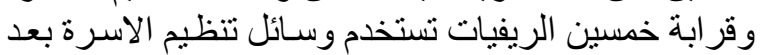

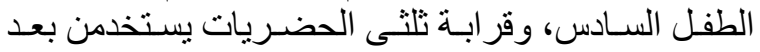

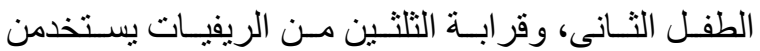

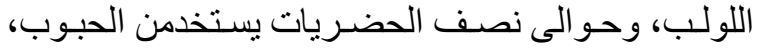

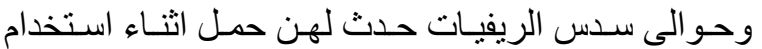
الوسيلة، و اقل من السدس من الحضريات حضث لهن حدث لهن الحمل

اثناء استخدام الوسيلة.

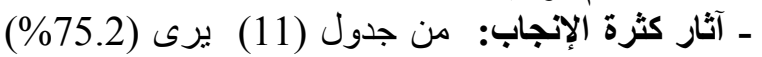
من الريفيات ان لكثرة الإنجاب آثار على على صحة الام

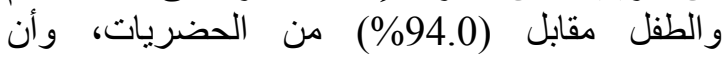


جدول ( 9): التوزيع العددى والنسبى لافراد عينة البحث بريف وحضر محافظة اسيوط حسب عدد الاطفال الاحياء، عدد الاطفال المرغوب في انجابه.

\begin{tabular}{|c|c|c|c|c|c|c|c|c|}
\hline \multicolumn{4}{|c|}{ حضر } & \multicolumn{4}{|c|}{ ريف } & \multirow{3}{*}{ العدد } \\
\hline \multicolumn{2}{|c|}{ عدد الاطفال المرغوب } & \multicolumn{2}{|c|}{ عدد الاطفال الذين ولدوا } & \multicolumn{2}{|c|}{ عدالم الاطفال } & \multicolumn{2}{|c|}{ علد الاطفال الذين } & \\
\hline$\%$ & عدد & $\%$ & عدد & $\%$ & عدد & $\%$ & عدد & \\
\hline- & - & - & - & - & - & 4.0 & 10 & طقل \\
\hline 33.2 & 83 & 42.8 & 107 & - & - & 2.4 & 6 & 2 \\
\hline 44.0 & 110 & 28.0 & 70 & 20.4 & 51 & 6.0 & 15 & 3 \\
\hline 16.8 & 42 & 10.0 & 25 & 24.8 & 62 & 23.2 & 58 & 4 \\
\hline 6.0 & 15 & 19.2 & 48 & 32.8 & 82 & 14.8 & 37 & 5 \\
\hline- & - & - & - & 22.0 & 55 & 49.6 & 124 & 6 فاكثر \\
\hline 100 & 250 & 100 & 250 & 100 & 250 & 100 & 250 & الاجمالى \\
\hline
\end{tabular}

جدول (10): التوزيع العددى والنسبى لافراد عينة البحث بريف وحضر محافظة اسيوط حسب بعض الامور المتعلقة بوسائل تنظيم

\begin{tabular}{|c|c|c|c|c|c|c|c|c|c|}
\hline & & & & & & & & & \\
\hline 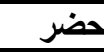 & & & & البيان & ضر | | | | بر & & ف & & البيان \\
\hline$\%$ & عدد & $\%$ & عدد & & $\%$ & عدد & $\%$ & عدد & \\
\hline 100.0 & 150 & 100.0 & 80 & جملة المستخدمات & 100.0 & 150 & 100.0 & 80 & جملة المستخدمات \\
\hline & & & & 3- المستخذمة الوسيلة & & & & & تنظيم الاسرة \\
\hline 53.3 & 80 & 22.5 & 18 & ـ حبوب & 60.0 & 150 & 32.0 & 80 & - نعم \\
\hline 26.0 & 39 & 62.5 & 50 & ـ لولب & 40.0 & 100 & 68.0 & 170 & - \\
\hline 10.0 & 15 & 12.5 & 10 & ـ ـ حقن & & & & & 1- ميعاد الاستخذام \\
\hline 10.7 & 16 & 2.5 & 2 & ـ عازل طب & 22.0 & 33 & - & - & ـ بعد الطقل الاول \\
\hline & & & & 4- حدوث حمل اثثاء & 60.0 & 90 & - & & ـ بعد الطقل الثانى \\
\hline 13.3 & 20 & 17.5 & 14 & الاستخدام & 10.7 & 16 & _ & - & ـ ـعد الطقل الثالث \\
\hline 86.7 & 130 & 82.5 & 66 & $y-$ & 7.3 & 11 & 25.0 & 20 & ـ بعد الطقل الرابع \\
\hline & & & & & & & 31.3 & 25 & - بعد الطقل الخامس \\
\hline & & & & & & & 43.7 & 35 & فاكثر بعد الطفل السادس \\
\hline
\end{tabular}

جدول (11) : التوزيع العددى والنسبى لافراد عينة البحث بريف وحضر محافظة اسيوط حسب بعض الاثار الجانبية لكثرة الانجاب.

\begin{tabular}{|c|c|c|c|c|c|c|c|c|c|c|c|c|}
\hline \multicolumn{6}{|c|}{ حضر } & \multicolumn{6}{|c|}{ ريف } & \multirow{3}{*}{ البيان } \\
\hline \multicolumn{2}{|c|}{ تقوى العلاقات } & \multicolumn{2}{|c|}{ 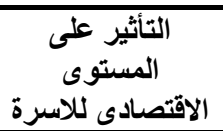 } & \multicolumn{2}{|c|}{ التأثير على صحة } & \multicolumn{2}{|c|}{ تقوى العلاقات } & \multicolumn{2}{|c|}{ 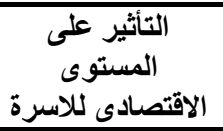 } & \multicolumn{2}{|c|}{ صحةة الام } & \\
\hline$\%$ & عدد & $\%$ & عدد & $\%$ & عدد & $\%$ & عدد & $\%$ & عدد & $\%$ & عدد & \\
\hline 29.2 & 73 & 95.2 & 238 & 94.0 & 235 & 68.8 & 172 & 58.4 & 146 & 75.2 & 188 & نعم \\
\hline 70.8 & 177 & 4.8 & 12 & 6,0 & 15 & 31.2 & 78 & 41.6 & 104 & 24.8 & 62 & $\gamma$ \\
\hline 100 & 250 & 100 & 250 & 100 & 250 & 100 & 250 & 100 & 250 & 100 & 250 & الاجمالى \\
\hline
\end{tabular}

المصدر : استمارة الاستبيان 


\begin{tabular}{|c|c|c|c|c|}
\hline \multicolumn{2}{|c|}{ حضر } & \multicolumn{2}{|c|}{ ريف } & 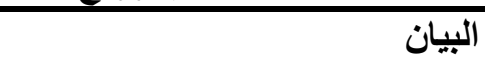 \\
\hline$\%$ & عدد & $\%$ & عدد & \multirow[t]{2}{*}{ جملة عدد المبحوثنات } \\
\hline \multirow[t]{2}{*}{100} & 250 & 100 & 250 & \\
\hline & & & & 1- طريقة اختيار الزوج \\
\hline 40.0 & 100 & 8.4 & 21 & ـ بنفسها \\
\hline \multirow[t]{2}{*}{60.0} & 150 & 91.6 & 229 & ـ عن طريق الاهل \\
\hline & & & & 2- صلة القرابة بين الزوجين \\
\hline 34.0 & 85 & 74.0 & 185 & \multirow{3}{*}{ 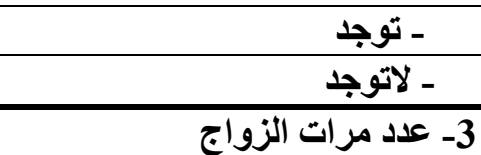 } \\
\hline \multirow[t]{2}{*}{66.0} & 165 & 26.0 & 65 & \\
\hline & & & & \\
\hline 96.0 & 240 & 76.0 & 190 & ـ مرة واحدة \\
\hline \multirow[t]{2}{*}{4.0} & 10 & 24.0 & 60 & \multirow{2}{*}{ - مرتان فاكثر } \\
\hline & & & & \\
\hline- & - & & - & 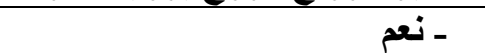 \\
\hline 100.0 & 250 & 100.0 & 250 & $y-$ \\
\hline
\end{tabular}

د-الانفتـاح على العـالم الخـارجى: يوضـح جدول (15) أن

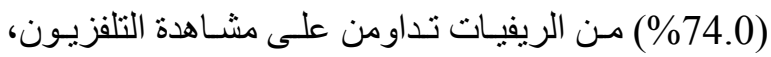

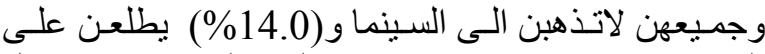

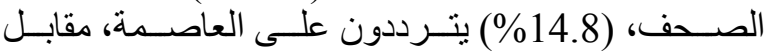

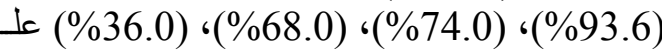

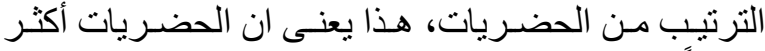

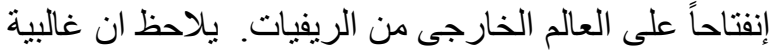

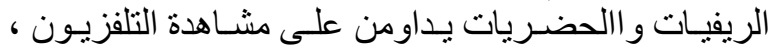

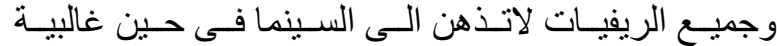
الحضريات يذهبن الى السينما. 3.2.10. بعض النواحى التعليمية للمراة الريفية التئية

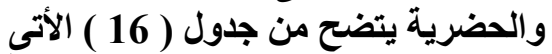

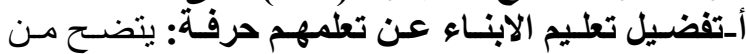

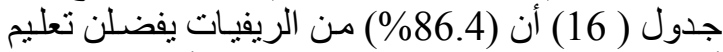

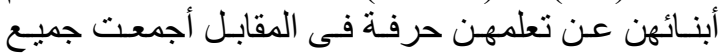
الريفيات على تفضلهزن تعليم الايناء بنسبة (100.0\%

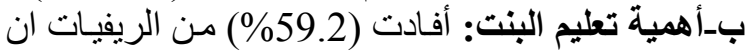

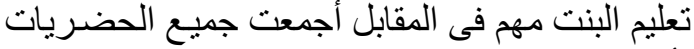

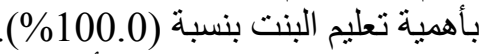

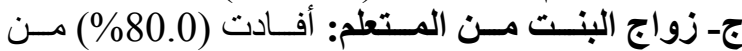

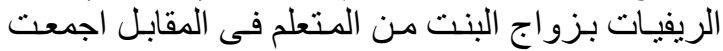

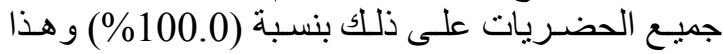

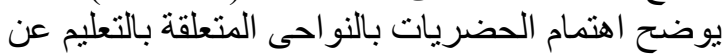

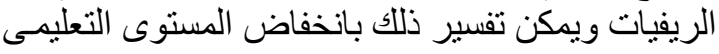

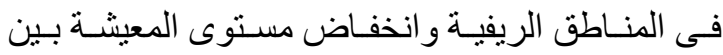

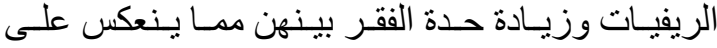

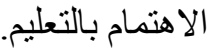

بـ المشـاركة في اتخـاذ القرارات : يتضـح مـن جـدول

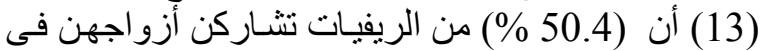
اتخاذ القرارت مقابل (72.0\%) من الحضريات.

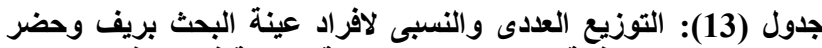

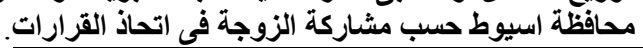

\begin{tabular}{|c|c|c|c|c|}
\hline \multicolumn{4}{|c|}{ مشاركة الزوج فى اتخاذ القرارات } & \multirow[b]{3}{*}{ 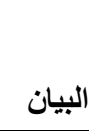 } \\
\hline \multicolumn{2}{|c|}{ عضر } & \multicolumn{2}{|c|}{ ريف } & \\
\hline$\%$ & عدد & $\%$ & عدد & \\
\hline 72.0 & 180 & 50.4 & 126 & نعم \\
\hline 28.0 & 70 & 49.6 & 124 & $y$ \\
\hline 100.0 & 250 & 100.0 & 250 & الاجمالى \\
\hline
\end{tabular}

المصدي : المتمارة الاستبيان

\section{ج-المشاركة المجتمعية}

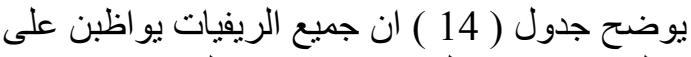

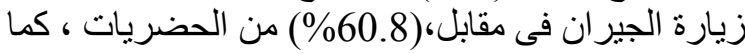

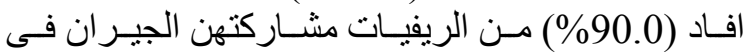

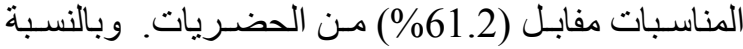

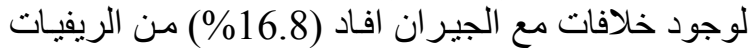

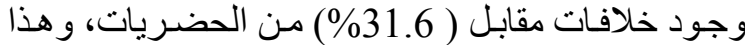

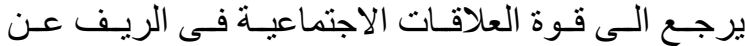

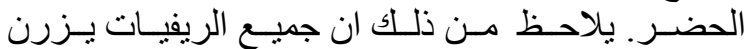

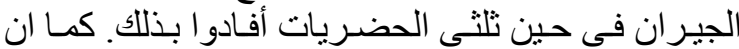

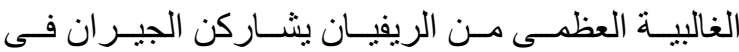

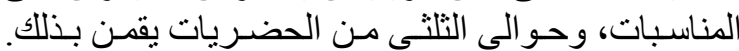

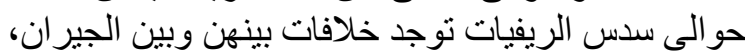
وحو الى الثلث من الحضريات أفادوا بذلك. 
جدول ( 14): التوزيع العددى والنسبى لافراد عينة البحث بريف وحضر محافظة اسيوط حسب علاقتتهم بجيرانهر.

\begin{tabular}{|c|c|c|c|c|c|c|c|c|c|c|c|c|}
\hline \multicolumn{6}{|c|}{ حضر } & \multicolumn{6}{|c|}{ ريف } & \multirow{3}{*}{ 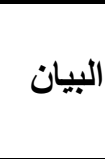 } \\
\hline \multicolumn{2}{|c|}{ وجود خلافات مع الجيران } & \multicolumn{2}{|c|}{ مشاركة الجيران فى المناسبات } & \multicolumn{2}{|c|}{ زيارة الجيران } & \multicolumn{2}{|c|}{ وجود خلافات مع الجيران } & \multicolumn{2}{|c|}{ مشاركة الجيران في المناسبات } & \multicolumn{2}{|c|}{ زيارة الجيران } & \\
\hline$\%$ & عدد & $\%$ & عداد & $\%$ & عدد & $\%$ & عداد & $\%$ & عدد & $\%$ & عدد & \\
\hline 31.6 & 79 & 61.2 & 153 & 60.8 & 152 & 16.8 & 42 & 90.0 & 225 & 100.0 & 250 & نعم \\
\hline 100.0 & 250 & 100.0 & 250 & 100.0 & 250 & 100.0 & 250 & 100.0 & 250 & 100.0 & 250 & 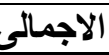 \\
\hline
\end{tabular}

جدول (15): التوزيع العددى والنسبى لافراد عينة البحث بريف وحضر محافظة اسيوط حسب الانفتاح على العالم الخارجى.

\begin{tabular}{|c|c|c|c|c|c|c|c|c|c|c|c|c|c|c|c|c|}
\hline \multicolumn{8}{|c|}{ حضر } & \multicolumn{8}{|c|}{ ريف } & \multirow{3}{*}{ البيان } \\
\hline \multicolumn{2}{|c|}{ التراصد على } & \multicolumn{2}{|c|}{ الاطلاع على } & \multicolumn{2}{|c|}{ الأهاب الى } & \multicolumn{2}{|c|}{ المداومة على على } & \multicolumn{2}{|c|}{ التردد على العاصمة } & \multicolumn{2}{|c|}{ الاطلاع على } & \multicolumn{2}{|c|}{ الأهاب اللى السينما } & \multicolumn{2}{|c|}{ مشاهدة التلفزيون على } & \\
\hline$\%$ & عدد & $\%$ & عدد & $\%$ & عدد & $\%$ & عدد & $\%$ & عدد & $\%$ & عدد & $\%$ & عدد & $\%$ & عدد & \\
\hline 36.0 & 90 & 68.0 & 170 & 74.0 & 185 & 93.6 & 234 & 14.8 & 37 & 14.0 & 35 & - & - & 74.0 & 185 & 'بع \\
\hline 64.0 & 160 & 32.0 & 80 & 26.0 & 65 & 6.4 & 16 & 85.2 & 213 & 86.0 & 215 & 100.0 & 250 & 26.0 & 65 & $y$ \\
\hline 100.0 & 250 & 100.0 & 250 & 100.0 & 250 & 100.0 & 250 & 100.0 & 250 & 100.0 & 250 & 100.0 & 250 & 100.0 & 250 & الاجمالح \\
\hline
\end{tabular}

جدول ( 16 ): التوزيع العددى والنسبي لافراد عينة البحث بريف وحضر محافظة اسيوط حسب بعض النواحى التعليمية.

\begin{tabular}{|c|c|c|c|c|c|c|c|c|c|c|c|c|}
\hline \multicolumn{6}{|c|}{ حضر } & \multicolumn{6}{|c|}{ ريف } & \multirow{3}{*}{ 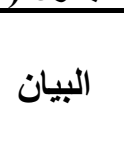 } \\
\hline \multicolumn{2}{|c|}{ زواج البنت من المتعلم } & \multicolumn{2}{|c|}{ الهمية تعليم البنت } & \multicolumn{2}{|c|}{ تفضيل تعليم الابناء عن تعلمهم حرفة } & \multicolumn{2}{|c|}{ زواج البنت من المتعلم } & \multicolumn{2}{|c|}{ الهمية تعليم البنت } & \multicolumn{2}{|c|}{ تفضيل تعليم الابناء عن تعلمهم حرفة } & \\
\hline$\%$ & عدد & $\%$ & عدد & $\%$ & عدد & $\%$ & عدد & $\%$ & عدد & $\%$ & عدد & \\
\hline 100.0 & 250 & 100.0 & 250 & 100.0 & 250 & 80.0 & 200 & 59.2 & 148 & 86.4 & 216 & نعم \\
\hline - & - & - & - & - & - & 20.0 & 50 & 40.8 & 102 & 13.6 & 34 & $y$ \\
\hline 100.0 & 250 & 100.0 & 250 & 100.0 & 250 & 100.0 & 200 & 100.0 & 250 & 100.0 & 250 & الاجمالى \\
\hline
\end{tabular}


الفرض البحثى الأول : هنـاك فروق معنويـة ببين المراة

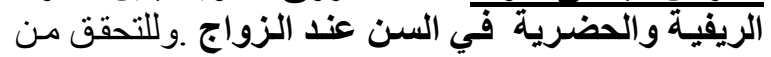

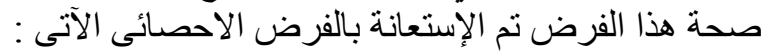
لا توجد فروق معنوية بين المرأة الريفية والحضن الحضرية في

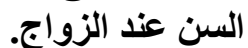

يتضـح مـن جدول (22) أن (66.0\%) مـن من الريفيـات

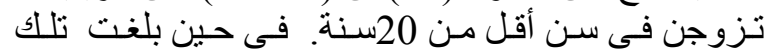
النسبة فى الحضر (17.6\%) أنسن

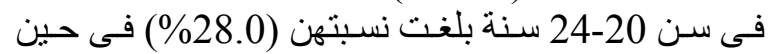

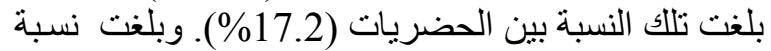

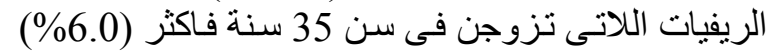

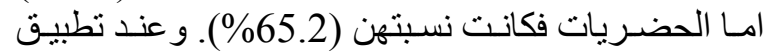

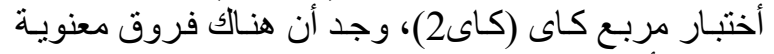

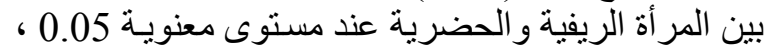

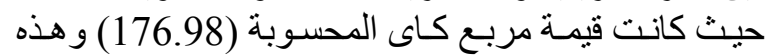

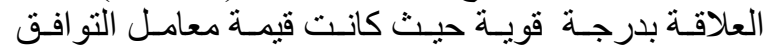

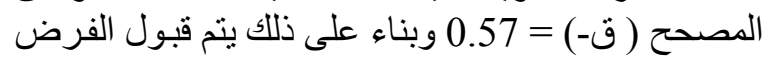

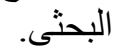

2-السن المفضل لزواج الذكور

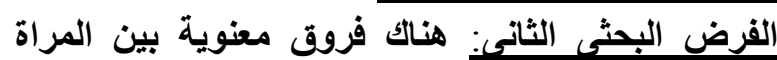

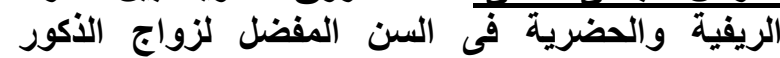

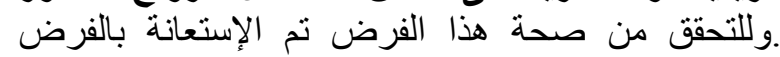

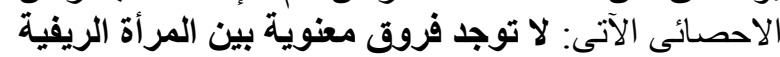

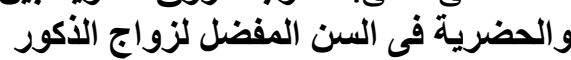

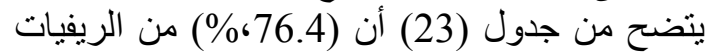

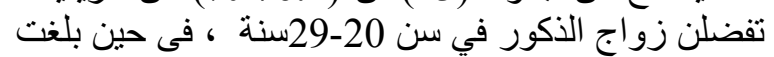

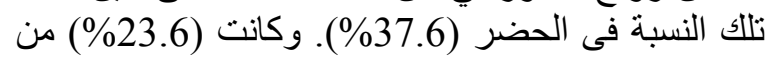

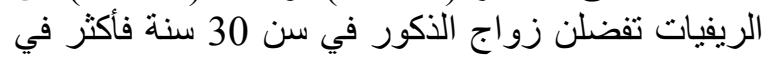

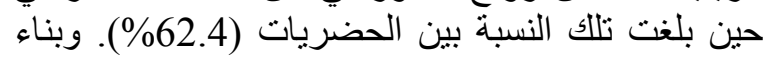

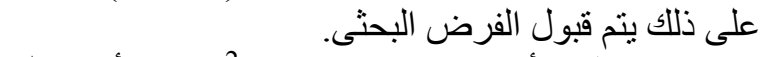

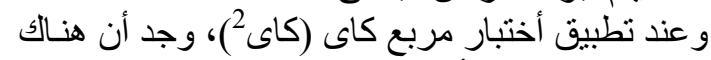

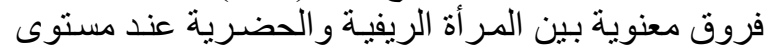

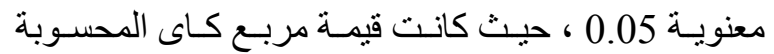

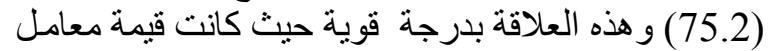

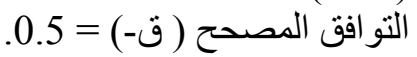

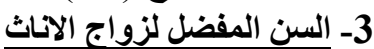

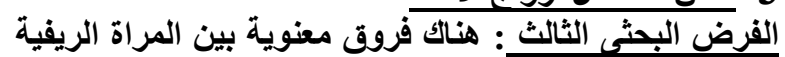

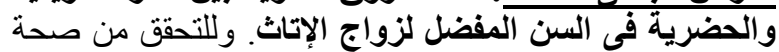

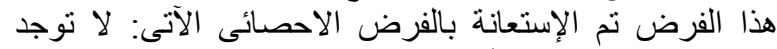

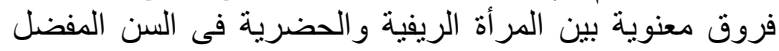

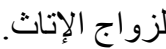

يتضح من جدول (24) أن (93.6\%) من الريفيات تفضلن

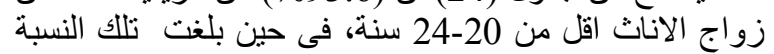

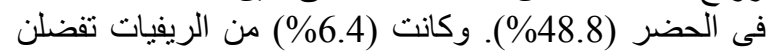

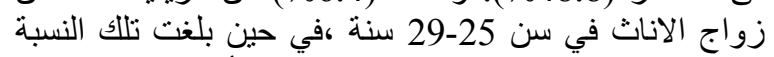

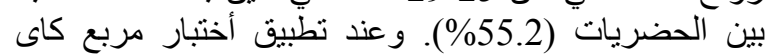

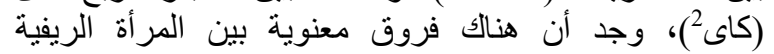

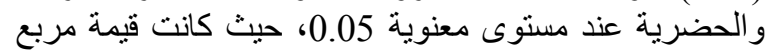

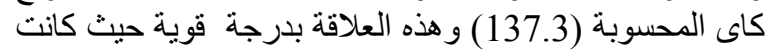

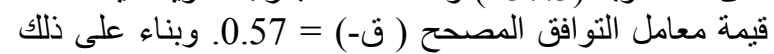

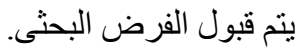

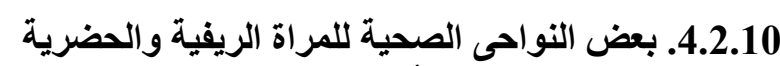

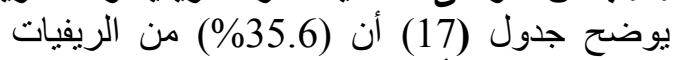

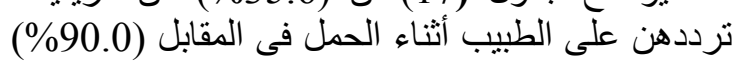

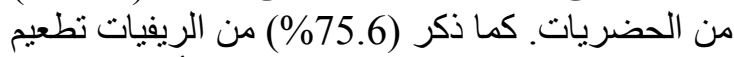

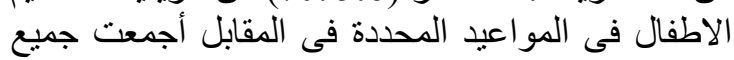

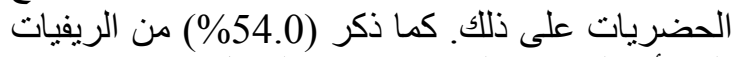

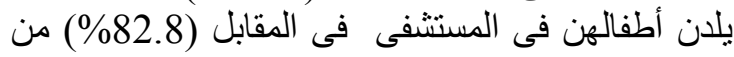

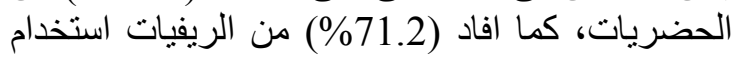

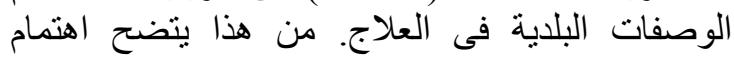
الحضريات بالنواحى الصحية عن الريفيات.

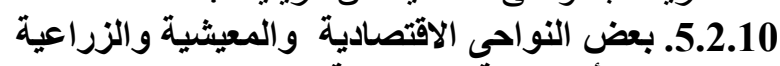
للمر أة الريفية والحضية الحضية أـ النواحى الاقتصادية

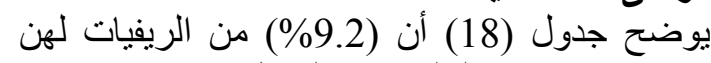

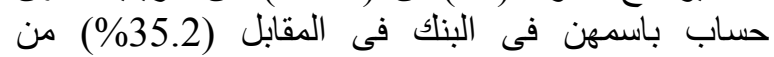

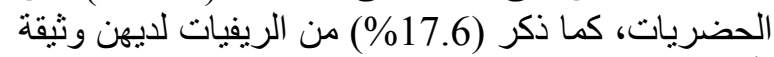

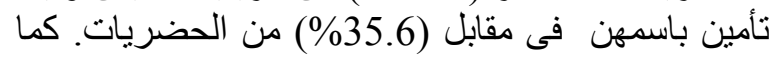

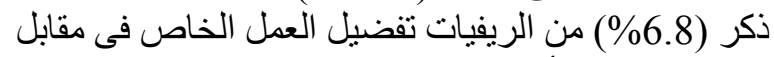

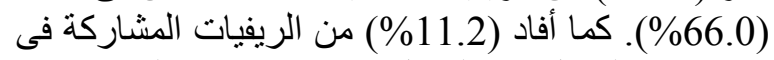

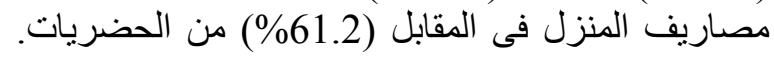

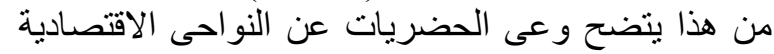

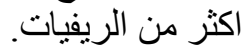
بـ النواحى المعيشية 1-الحالة الصحية للمسكن المعنة

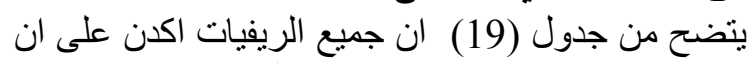

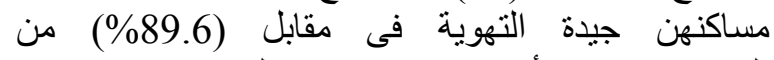

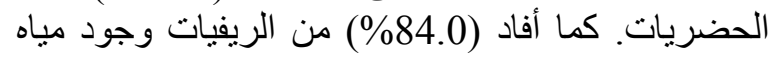

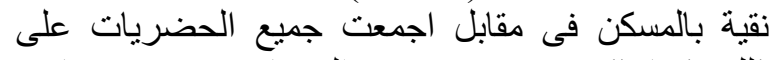

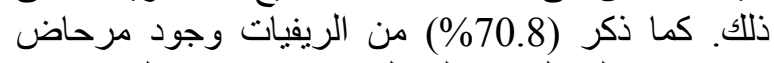
صحى فى المنزل فى المقابل اجمعت جمبع الحضريات وجرد مردات

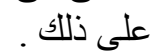
2- 2 خصائص المسكن

يلاحظ من جدول (20) (94.0\%) من المن من الريفيات أفادن

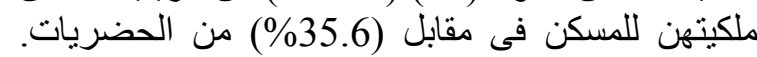

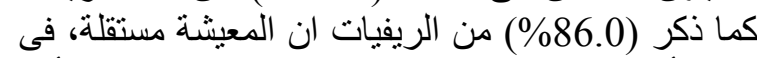

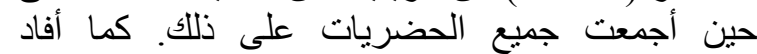

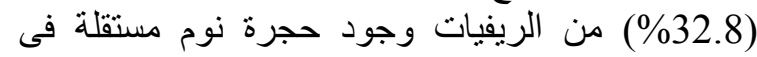
مقابل (88.8\%) من الحضريات.

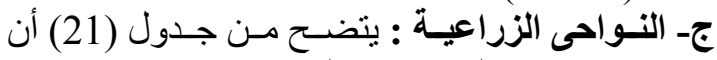

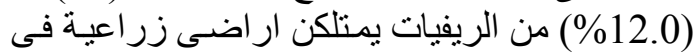
المقابل (8.4\%) من الحضريات. كما افـاد (25.6\% (96.0\%) من الريفيات تربية الدو اجن في مقابل (25.6\%) من كن

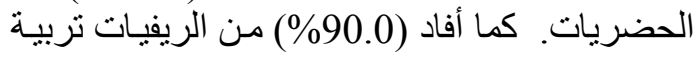
الحيو انات.

اختبار فروض البحث

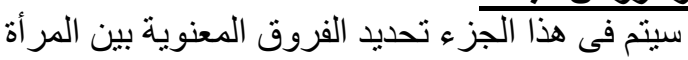

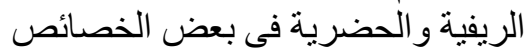

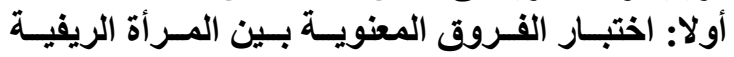

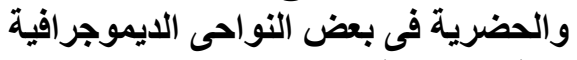
1-السن عند الزواج 
جدول (17): التوزيع العددى والنسبى لافراد عينة البحث بريف وحضر محافظة اسيوط حسب بعض النواحى الصحية.

\begin{tabular}{|c|c|c|c|c|c|c|c|c|c|c|c|c|}
\hline \multicolumn{6}{|c|}{ حضر } & \multicolumn{6}{|c|}{ ريف } & \multirow{3}{*}{ البيان } \\
\hline \multicolumn{2}{|c|}{ البتلذية في الوصلاج العلات } & \multicolumn{2}{|c|}{ المواظبة على تطعيم } & \multicolumn{2}{|c|}{ التردد على الطبيب اثناء } & \multicolumn{2}{|c|}{ البلدية في العلاج الوصفات } & \multicolumn{2}{|c|}{ المواظبة على تطعيم } & \multicolumn{2}{|c|}{ التردد على الطبيب } & \\
\hline$\%$ & عدد & $\%$ & عدد & $\%$ & عدد & $\%$ & عدد & $\%$ & عدد & $\%$ & عدد & \\
\hline 16.0 & 40 & 100.0 & 250 & 90.0 & 225 & 71.2 & 178 & 75.6 & 189 & 53.6 & 134 & نعم \\
\hline 84.0 & 210 & - & $\begin{array}{ll}- \\
-\end{array}$ & 10.0 & 25 & 28.8 & 72 & 24.4 & 61 & 46.4 & 116 & ل \\
\hline 100.0 & 250 & 100.0 & 250 & 100.0 & 250 & 100.0 & 250 & 100.0 & 250 & 100.0 & 250 & الاجمالى \\
\hline
\end{tabular}

جدول (18) : التوزيع العدىى و النسبى لافراد عينة البحث بريف وحضر محافظة اسيوط حسب بعض النواحى الاقتصادية.

\begin{tabular}{|c|c|c|c|c|c|c|c|c|c|c|c|c|c|c|c|c|}
\hline \multirow{2}{*}{\multicolumn{2}{|c|}{ مصاريف المشاركة في }} & \multicolumn{6}{|c|}{ حضر } & \multicolumn{8}{|c|}{ ريف } & \multirow{3}{*}{ البيان } \\
\hline & & \multicolumn{2}{|c|}{ تفضيل العمل } & \multicolumn{2}{|c|}{ لايها وثُيقة تأمين } & \multicolumn{2}{|c|}{ حساب باسمها في } & \multicolumn{2}{|c|}{ مصاريف المنزلى } & \multicolumn{2}{|c|}{ تفضيل العمل } & \multicolumn{2}{|c|}{ وثيقة تأمين } & \multicolumn{2}{|c|}{ حساب فى البنك } & \\
\hline$\%$ & عدد & $\%$ & عدد & $\%$ & عدد & $\%$ & عدد & $\%$ & عدد & $\%$ & عدد & $\%$ & عدد & $\%$ & عدد & \\
\hline 61.2 & 153 & 66.0 & 165 & 35.6 & 89 & 35.2 & 88 & 11.2 & 28 & 6.8 & 17 & 17.6 & 44 & 9.2 & 23 & نعم \\
\hline 38.8 & 97 & 34.0 & 85 & 64.4 & 161 & 64.8 & 162 & 88.8 & 222 & 93.2 & 233 & 82.4 & 206 & 90.8 & 227 & $\gamma$ \\
\hline 100 & 250 & 100 & 250 & 100 & 250 & 100 & 250 & 100 & 250 & 100 & 250 & 100 & 250 & 100 & 250 & الاجمالى \\
\hline
\end{tabular}

جدول (19): التوزيع العددى والنسبى لافر اد عينة البحث بريف وحضر محافظة اسيوط حسب الحالة الصحية للمسكن.

\begin{tabular}{|c|c|c|c|c|c|c|c|c|c|c|c|c|}
\hline \multicolumn{6}{|c|}{ حضر } & \multicolumn{6}{|c|}{ ريف } & \multirow[t]{3}{*}{ البيان } \\
\hline \multicolumn{2}{|c|}{ وجود محرح } & \multicolumn{2}{|c|}{ وجود مياه نقية } & \multicolumn{2}{|c|}{ السكن جيد التهوية } & \multicolumn{2}{|c|}{ وجود مرحي } & \multicolumn{2}{|c|}{ وجود مياه نقية } & \multicolumn{2}{|c|}{ التهونية جيا } & \\
\hline$\%$ & عدد & $\%$ & عدد & $\%$ & عدد & $\%$ & عدد & $\%$ & عدد & $\%$ & عدد & \\
\hline 100.0 & 250 & 100.0 & 250 & 89.6 & 224 & 70.8 & 177 & 84.0 & 210 & 100.0 & 250 & نعم \\
\hline - & - & - & - & 10.4 & 26 & 29.2 & 73 & 16.0 & 40 & - & - & $y$ \\
\hline 100.0 & 250 & 100.0 & 200 & 100.0 & 250 & 100.0 & 250 & 100.0 & 250 & 100.0 & 250 & الاجمالى \\
\hline
\end{tabular}


جدول (20): التوزيع العددى و النسبى لافراد عينة البحث بريف وحضر محافظة اسيوط حسب خصائص المسكن.

\begin{tabular}{|c|c|c|c|c|c|c|c|c|c|c|c|c|}
\hline \multicolumn{6}{|c|}{ حضر } & \multicolumn{6}{|c|}{ ريف } & \multirow[t]{3}{*}{ البيان } \\
\hline \multicolumn{2}{|c|}{ وجود حجرة نوم مستقلة } & \multicolumn{2}{|c|}{ المعيشة المستقلة } & \multicolumn{2}{|c|}{ ملكية السكن } & \multicolumn{2}{|c|}{ وجود حجرة نوم مستقلة } & \multicolumn{2}{|c|}{ المعيشة المستقلة } & \multicolumn{2}{|c|}{ ملكية السكن } & \\
\hline$\%$ & عدد & $\%$ & عدد & $\%$ & عدد & $\%$ & عدد & $\%$ & عداد & $\%$ & عدد & \\
\hline 88.8 & 222 & 100.0 & 250 & 35.6 & 89 & 32.8 & 82 & 86.0 & 215 & 94.0 & 235 & نعم \\
\hline 11.2 & 28 & - & - & 64.4 & 161 & 67.2 & 168 & 14.0 & 35 & 6.0 & 15 & $\gamma$ \\
\hline 100.0 & 250 & 100.0 & 250 & 100.0 & 250 & 100.0 & 250 & 100.0 & 250 & 100.0 & 250 & الاجمالى \\
\hline
\end{tabular}

جدول ( 21 ): التوزيع العدىى والنسبى لافراد عينة البحث بريف وحضر محافظة اسيوط حسب بعض النواحى الزراعية.

\begin{tabular}{|c|c|c|c|c|c|c|c|c|c|c|c|c|}
\hline \multicolumn{6}{|c|}{ حضر } & \multicolumn{6}{|c|}{ ريف } & \multirow[t]{3}{*}{ البيان } \\
\hline \multicolumn{2}{|c|}{ تربية الحيوانات } & \multicolumn{2}{|c|}{ تربية الدواجن } & \multicolumn{2}{|c|}{ ملكية الارض } & \multicolumn{2}{|c|}{ تربية الحيوانات } & \multicolumn{2}{|c|}{ تربية الدواجن } & \multicolumn{2}{|c|}{ ملكية الارض } & \\
\hline$\%$ & عدد & $\%$ & عدد & $\%$ & عدد & $\%$ & عدد & $\%$ & عدد & $\%$ & عدد & \\
\hline- & - & 25.6 & 64 & 8.4 & 21 & 90.0 & 225 & 96.0 & 240 & 12.0 & 30 & نعم \\
\hline 100.0 & 250 & 74.4 & 186 & 91.6 & 229 & 10.0 & 25 & 4.0 & 10 & 88.0 & 220 & $y$ \\
\hline 100.0 & 200 & 100.0 & 250 & 100.0 & 250 & 100.0 & 200 & 100.0 & 200 & 100.0 & 250 & الاجمالى \\
\hline
\end{tabular}


جدول ( 22) : التوزيع العددى والنسبى للمرأة بريف وحضر محافظة اسيوط حسب السن عند الزواج.

\begin{tabular}{|c|c|c|c|c|c|}
\hline جملة & \multicolumn{2}{|c|}{ حضر } & \multicolumn{2}{|c|}{ ريف } & \multirow[t]{2}{*}{ السن عند الزواج } \\
\hline & $\%$ & عدد & $\%$ & عدد & \\
\hline 209 & 17.6 & 44 & 66.0 & 165 & اقل من 20سنة \\
\hline 113 & $\overline{17.2}$ & 43 & 28.0 & 70 & $24-20$ \\
\hline 178 & 65.2 & 163 & 6.0 & 15 & 25فأكثر \\
\hline 500 & 100.0 & 250 & 100.0 & 250 & الاجمالح \\
\hline
\end{tabular}

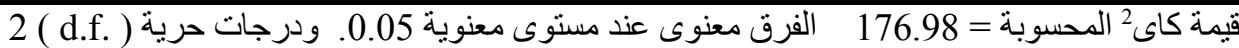

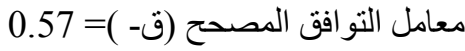
قيمة كاى الجدولية = 5.99

جدول ( 23): التوزيع العددى و النسبى للمرأة بريف وحضر محافظة اسيوط حسب السن المفضل لزواج الذكور.

\begin{tabular}{|c|c|c|c|c|c|}
\hline \multirow[t]{2}{*}{ جملة } & \multicolumn{2}{|c|}{ حضر } & \multicolumn{2}{|c|}{ ريف } & \multirow{2}{*}{ السن المفضل لزواج } \\
\hline & $\%$ & عدد & $\%$ & عدد & \\
\hline 285 & 37.6 & 94 & 76.4 & 191 & اقل من 20 -29 \\
\hline 215 & 62.4 & 156 & 23.6 & 59 & 30 سنة فاكثر \\
\hline 500 & 100.0 & 250 & 1000 & 250 & الاجمالى \\
\hline
\end{tabular}

1 ( d.f. ) الفرق معنوى عند مستوى معنوية 0.05. ودرجات حرية

معامل التو افق المصحح (ق) - =

قيمة كاى $25.2=$

قيمة كاى الجدولية = 3.84

جدول ( 24): التوزيع العددى والنسبى للمر أة بريف وحضر محافظة اسيوط حسب السن المفضل لزواج الاناث.

\begin{tabular}{|c|c|c|c|c|c|}
\hline \multirow[t]{2}{*}{ جملة } & \multicolumn{2}{|c|}{ حضر } & \multicolumn{2}{|c|}{ ريف } & \multirow[t]{2}{*}{ السن المفضل لزواج الاناث } \\
\hline & $\%$ & عدد & $\%$ & عدد & \\
\hline 346 & 48.8 & 112 & 93.6 & 234 & ققل من 20 -24 \\
\hline 154 & 55.2 & 138 & 6.4 & 16 & $29-25$ \\
\hline 500 & 100.0 & 250 & 100.0 & 250 & الاجمالى \\
\hline
\end{tabular}

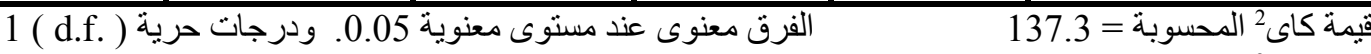

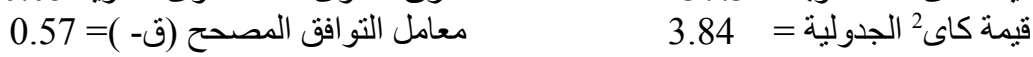

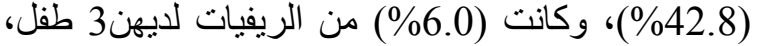
في حين بلغت تللك النسبة بين الحضريات (28.0\%).

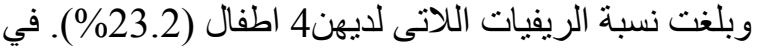
حين كانت تلك النسبة بين الحضريات (10.0\%). نسبة الريفيات اللاتى لديهن 5أطفال فأكثر (64.4\%) في (19) في

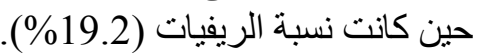

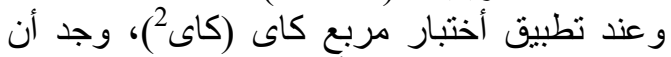

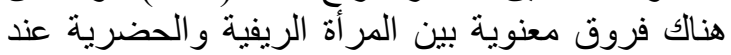

4- عدد الاطفال الذين ولاوا أحياء

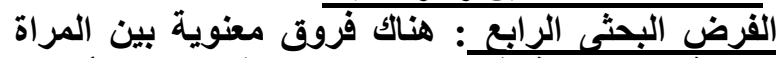

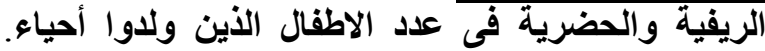

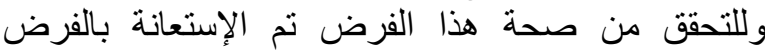

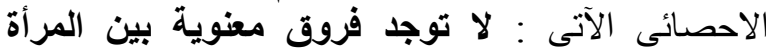
الريفية والحضرية فى عدد الاطفال الأين ولاون الأوا أحياء

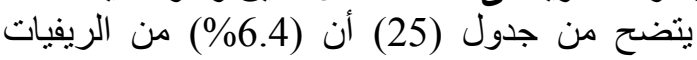
لديهن 1-2 طفل، فى حين بلغت تلك النسبة في الحضر

جدول ( 25): التوزيع العددى و النسبى للمرأة بريف وحضر محافظة اسيوط حسب عدد الاطفال الذين ولدوا أحياء.

\begin{tabular}{|c|c|c|c|c|c|}
\hline \multirow[t]{2}{*}{ جملة } & \multicolumn{2}{|c|}{ حضر } & \multicolumn{2}{|c|}{ ريف } & \multirow[t]{2}{*}{ عدد الاطفال الذين ولدوا احياء } \\
\hline & $\%$ & عدد & $\%$ & عدد & \\
\hline 123 & 42.8 & 107 & 6.4 & 16 & 2-1 طقل \\
\hline 85 & 28.0 & 70 & 6.0 & 15 & 3 \\
\hline 83 & 10.0 & 25 & 23.2 & 58 & 4 \\
\hline 209 & 19.2 & 48 & 64.4 & 161 & 5 5 \\
\hline$\overline{500}$ & 100.0 & 250 & $\overline{100.0}$ & 250 & الاجمالى \\
\hline
\end{tabular}


جدول (27): التوزيع العددى والنسبى للمرأة بريف وحضر محافظة اسيوط حسب استخدام وسائب تنظيم الأسرة.

\begin{tabular}{|c|c|c|c|c|c|}
\hline \multirow[t]{2}{*}{ جملة } & \multicolumn{2}{|c|}{ حضر } & \multicolumn{2}{|c|}{ ريف } & استخدام وسائل \\
\hline & $\%$ & عدد & $\%$ & عدد & تنظيم الاسرة \\
\hline 230 & 60.0 & 150 & 32.0 & 80 & 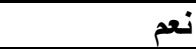 \\
\hline 270 & 40.0 & 100 & 68.0 & 170 & $\bar{y}$ \\
\hline 500 & 100.0 & 250 & 100.0 & 250 & الاجمالى \\
\hline
\end{tabular}

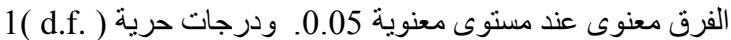

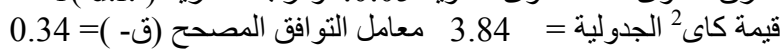

ثانيا: اختبار الفروق المعنوية بين المرأة الريفية

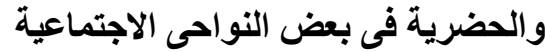

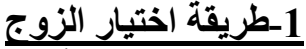

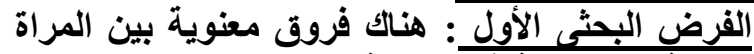

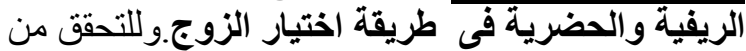

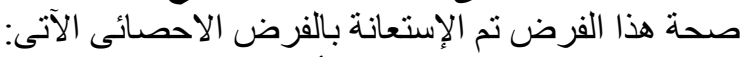

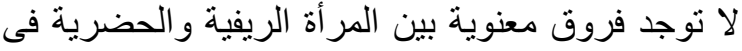

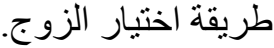

يتضح من جدول (28) أن (8.4\%) من الريفيات

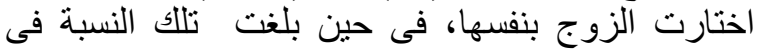
الحضر (40.0\%)، (91.6\%) من الريفيات افلادن باختيار

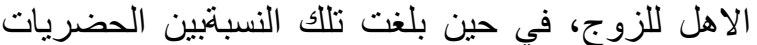

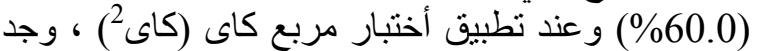

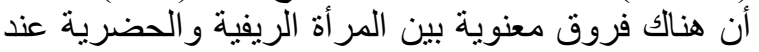

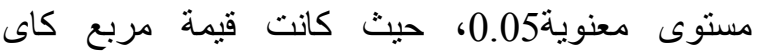

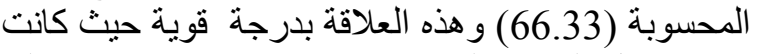

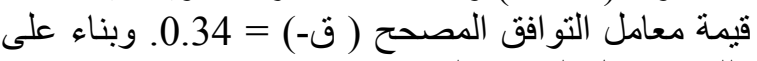

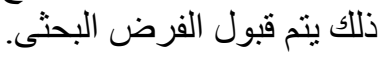

جدول ( 28): التوزيع العددى والنسبى للمرأة بريف وحضر محافظة اسيوط حسب استخدام وسائل تنظيم الأسرة.

\begin{tabular}{|c|c|c|c|c|c|}
\hline \multirow[t]{2}{*}{ جملة } & \multicolumn{2}{|c|}{ حضر } & \multicolumn{2}{|c|}{ ريف } & \multirow{2}{*}{ طريقة اختيار } \\
\hline & $\%$ & عدد & $\%$ & عدد & \\
\hline 121 & 40.0 & 100 & 8.4 & 21 & بنفسها \\
\hline 379 & 60.0 & 150 & 91.6 & 229 & الاهل \\
\hline 500 & 100.0 & 250 & 100.0 & 250 & الاجمالى \\
\hline
\end{tabular}

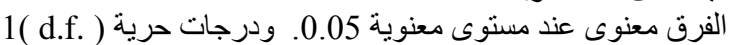
قيمة كاى $2.84=$ معامل التو افق المصحح (ق) ) = 0.34

2 الفرضلة القرابة

الفرض البحثخ الثرابة الثئي: هناك فروق معنوية بين المراة

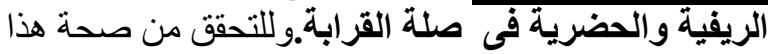

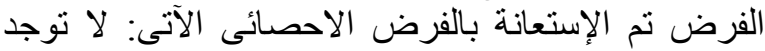

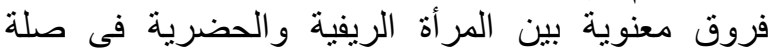

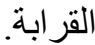

يتضح من جدول (29) أن (74.0\%) من الرئة) فئيات

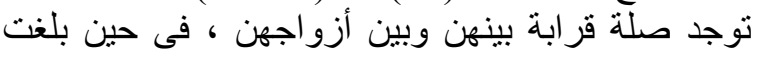

مستوى معنوية 0.05، حيث كانت قيمة مربع كاى المحسوبة (176.8) و هذه العلاقة بدرجة قوية حيثة حيثة

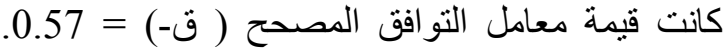
وبناء على ذللك يتم قبول الفرض التئ البحثى.

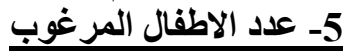

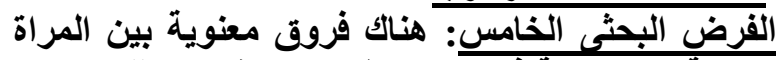

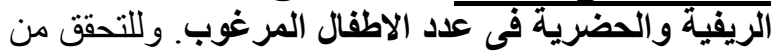

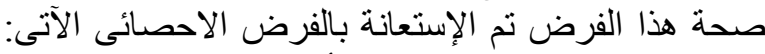

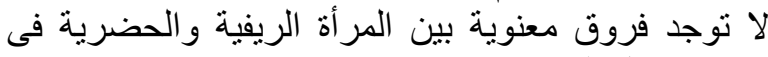

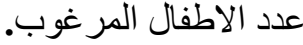

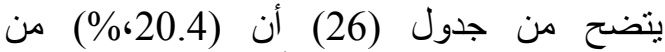

الريفيات ترغبن في انجاب 2- 3 أطفال، في حين بلغت (26)

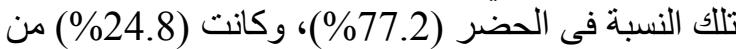

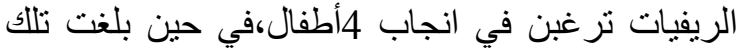

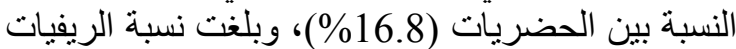

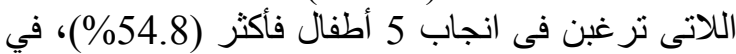

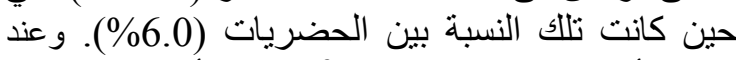

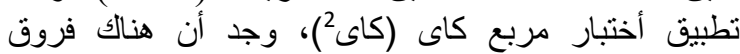

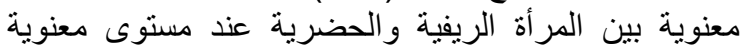
0.05 ، حيث كانت قيمة مربع كاى المحسوبة (184.24) و هذه العلاقة بدرجة قوية حيث كانت قيمة كانة معامل التوافق المصحح ( ق-) = 0,57. وبناء على ذلك ينم قبول فئ الفرض

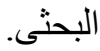

جدول ( 26): التوزيع العددى والنسبى للمرأة بريف وحضر محافظة اسيوط حسب عدد الاطفال المرغوب.

\begin{tabular}{|c|c|c|c|c|c|}
\hline \multirow[t]{2}{*}{ جملة } & \multicolumn{2}{|c|}{ حضر } & \multicolumn{2}{|c|}{ ريف } & \multirow{2}{*}{ عدلد الاطفال } \\
\hline & $\%$ & عدد & $\%$ & عدد & \\
\hline 244 & 77.2 & 193 & 20.4 & 51 & 3-2 \\
\hline 104 & 16.8 & 42 & 24.8 & $\overline{62}$ & $\overline{4}$ \\
\hline 152 & 6.0 & 15 & 54.8 & 137 & $\overline{+5}$ \\
\hline 500 & 100.0 & 250 & 100.0 & 250 & الاجمالي \\
\hline
\end{tabular}

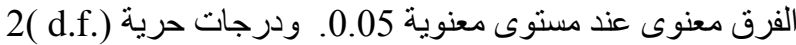
قيمة كاى $5.99=$

6-استخدام وسائل تنظيم الاسرة

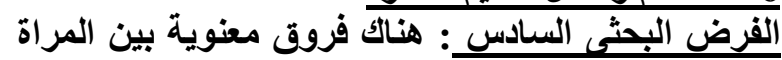

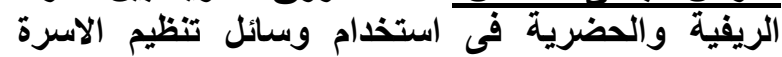

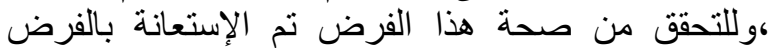

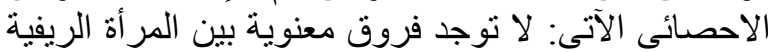
و الحضرية فى استخدام وسائل تنظيم الاسرة. يتضح من جدول (27) أن (32.4\%) من الرين الريفيات

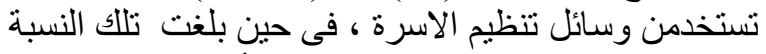
فى الحضر (60.0\%) و عند تطبيق أختبار مربع كائ فئن

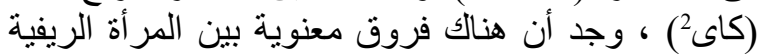

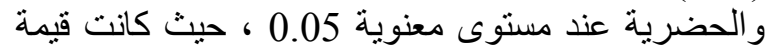

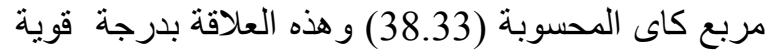
حيث كانت قيمة معامل التو افق المصحح ( قلى ) = وبناء على ذلك يتم قبول الفرض الته البحثى. 


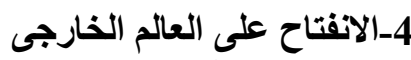

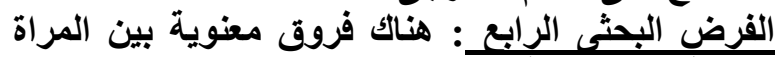

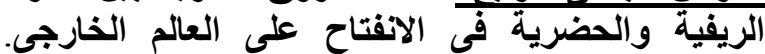

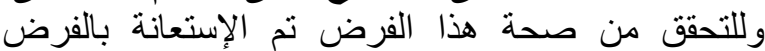

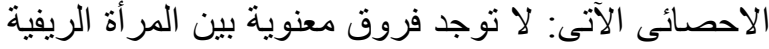
و الحضرية فى الانفتاح على العالم الخارجى.

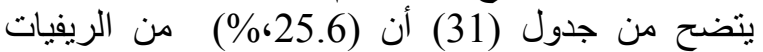

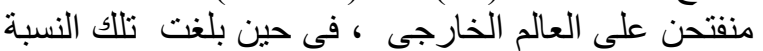

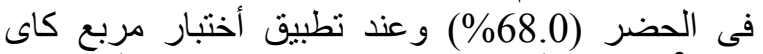

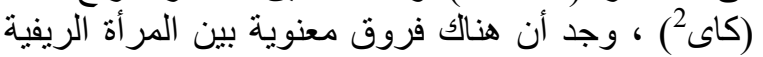

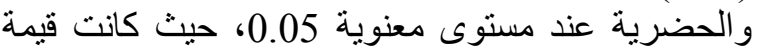
مربع كاى المحسوبة (88.56) و هذه العلاقة بدرجة قدية قوية

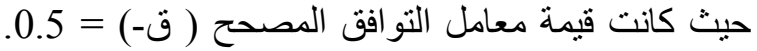
وبناء على ذلك يتم قبول الفرض البـ البحثى.

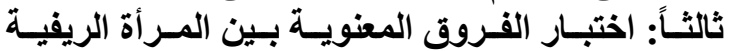

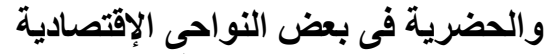

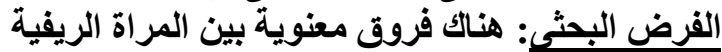

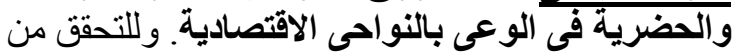

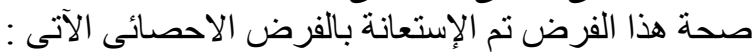

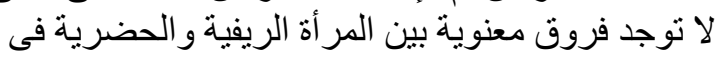
الو عى بالنواحى الاقتصادية. يتضح من جدول (32) أن (11.2\%) ليس عدهن

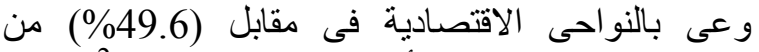

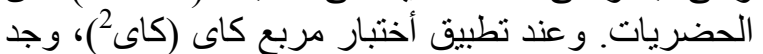

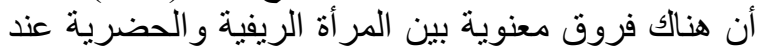

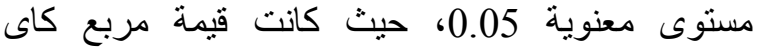
المحسوبة (103.9) و هذه العلاقة بدرجة قوية قاية حيث كانت قيمة معامل التوافق المصحح ( قلى ) = 0.5. ذللك يتم قبول الفرض البوافت البحثى.

رابعاً: اختبار الفروق الفرض المعنوية بين المرأة الريفية

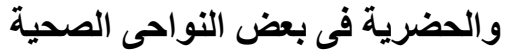

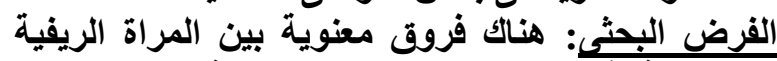

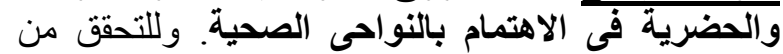

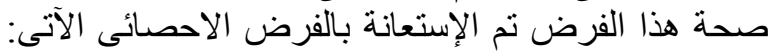
لا نوجد فروق معنوية بين المرأة الريفية والحضية الحضرية فى الاحي الاهتمام بالنو احى الصحية.

يتضح من جدول (33) ان (66.8\%) من الريفيات

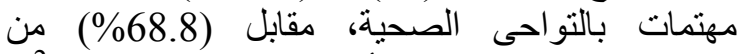
الحضريات. وعند تطبيق أختبار مربع كاى (كاى2)،

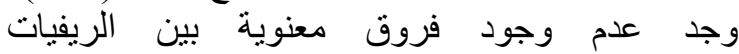
والحضريات. وبناء على ذود ذلك ينم قبول لين الفرض.

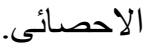

جدول (29): التوزيع العددى والنسبى للمرأة بريف وحضر محافظة اسيوط حسب صيلة القزابة.

\begin{tabular}{|c|c|c|c|c|c|}
\hline \multirow[b]{2}{*}{ جملة جملة } & \multicolumn{2}{|c|}{ حضر } & \multicolumn{2}{|c|}{ ريف } & \multirow[t]{2}{*}{ صلة القرابة } \\
\hline & $\%$ & عدد & $\%$ & عدد & \\
\hline 270 & 34.0 & 85 & 74.0 & 185 & توجل \\
\hline 230 & 66.0 & 165 & 26.0 & 65 & لاتوجد \\
\hline 500 & 100.0 & 250 & 100.0 & 250 & الاجمالح \\
\hline
\end{tabular}

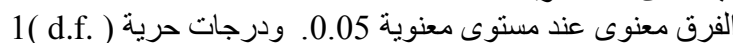

قيمة كاى2 الجدولية = 3.84 معامل التو افق المصحح (ق- ) = 0.5

تللك النسبة فى الحضر (34.0\%) و وعند نطبيق أختبار

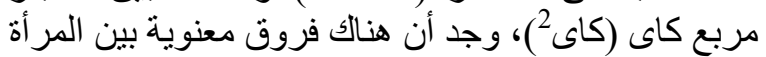

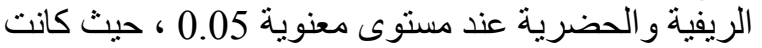
قيمة مربع كاى المحسوبة (78.9) و هذه العلاقة بدرجة

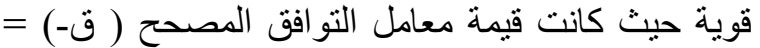

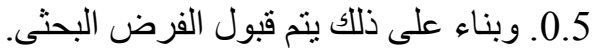
3-المشاركة في اتخاذ القرارات

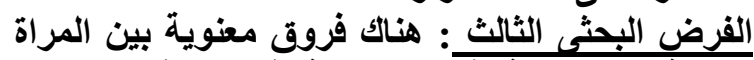

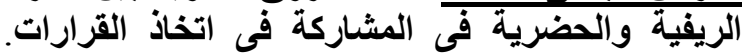

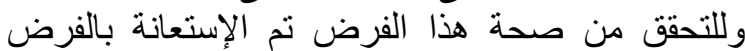

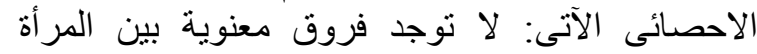

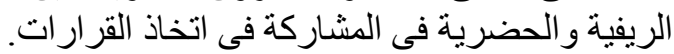

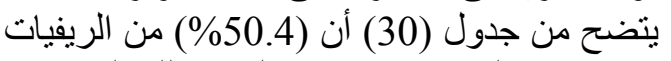

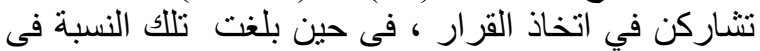

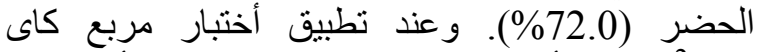
(كاى2)، وجد أن هنالك فروق معنوية بين المرأة أرئ الريفية

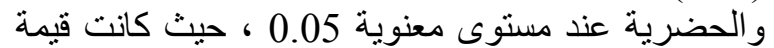
مربع كاى المحسوبة (23.65) وهذه العة العلاقة بدرجة قويةحيث كانت قيمة معامل التو افق المصحح (ق-

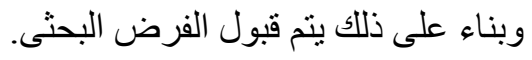

جدول ( 30): التوزيع العددى والنسبى للمرأة بريف وحضر محافظة اسيوط حسب المشاركة في اتخاذ القرار.

\begin{tabular}{|c|c|c|c|c|c|}
\hline \multirow[t]{2}{*}{ جملة } & \multicolumn{2}{|c|}{ حضر } & \multicolumn{2}{|c|}{ ربف } & المشاركة \\
\hline & $\%$ & عدد & $\%$ & عدد & في التخاذ \\
\hline 306 & 72.0 & 180 & 50.4 & 126 & نعم \\
\hline 194 & 28.0 & 70 & 49.6 & 124 & ע \\
\hline 500 & 100.0 & 250 & 100.0 & 250 & الاجمالي \\
\hline
\end{tabular}

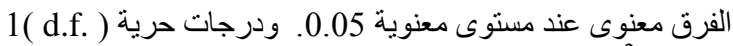
قيمة كاى2 الجدولية = 3.84 م معامل التو افق المصحح (ق- ) =0.23 


\begin{tabular}{|c|c|c|c|c|c|}
\hline \multirow[t]{2}{*}{ جملة } & \multicolumn{2}{|c|}{ حضر } & \multicolumn{2}{|c|}{ ريف } & \multirow[t]{2}{*}{ الانفتاح على العالم الخارجى } \\
\hline & $\%$ & عدد & $\%$ & عدد & \\
\hline 234 & 68.0 & 170 & 25.6 & 64 & نعم \\
\hline 266 & 32.0 & 80 & 74.4 & 186 & $\bar{y}$ \\
\hline 500 & 100.0 & 250 & 100.0 & 250 & الاجمالى \\
\hline
\end{tabular}

جدول (32): التوزيع العددى والنسبى للمر أة بريف وحضر محافظة اسيوط حسب الوعى بالنواحى الاقتصادية.

\begin{tabular}{|c|c|c|c|c|c|}
\hline \multirow[t]{2}{*}{ جملة } & \multicolumn{2}{|c|}{ حضر } & \multicolumn{2}{|c|}{ ريف } & \multirow{2}{*}{ النواحى الاقتصادية } \\
\hline & $\%$ & عدد & $\%$ & عدد & \\
\hline 152 & 49.6 & 124 & 11.2 & 28 & وعى \\
\hline 348 & 50.4 & 126 & 88.8 & 222 & عدم وعى \\
\hline 500 & 100.0 & 250 & 100.0 & 250 & الاجمالى \\
\hline
\end{tabular}

جذول ( 33): التوزيع العددى و النسبى للمرأة بريف وحضر محافظة اسيوط حسب الاهتمام بالنواحى الصحية.

\begin{tabular}{|c|c|c|c|c|c|}
\hline \multirow[t]{2}{*}{ جملة } & \multicolumn{2}{|c|}{ حضر ( حضر } & \multicolumn{2}{|c|}{ ريف } & \multirow[t]{2}{*}{ النواحى الصحية } \\
\hline & $\%$ & عدد & $\%$ & عدد & \\
\hline 339 & 68.8 & 172 & 66.8 & 167 & الاهتمام بالنواحى الصحية \\
\hline 161 & 31.2 & 78 & 33.2 & 83 & عدم الاهتمام بالنواحى الصحية \\
\hline$\overline{500}$ & 100.0 & 250 & 100.0 & 250 & الاجمالى \\
\hline
\end{tabular}

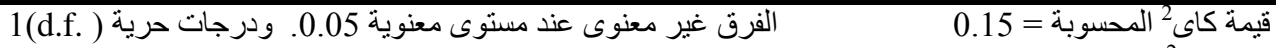

قيمة كاى الجدولية = 3.84

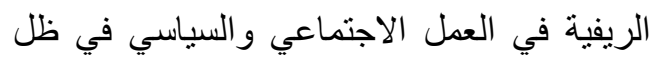

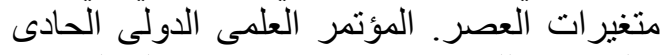

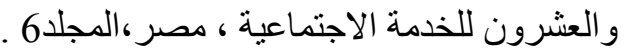

Website, https://.mandumah.com/ Retrieved April.2018,12: 2PM

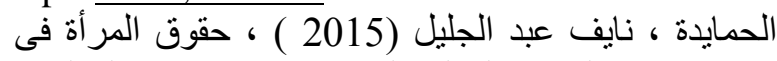

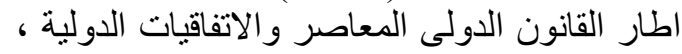

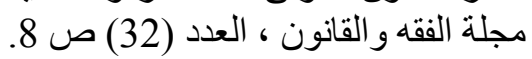

Website,https://www.researchgate.net/.../284218

379_hqwq_almrat_fy_atar_alqanwn_aldwly_al..

Retrieved April.2018,10:51AM

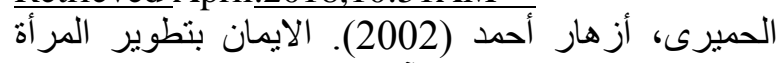

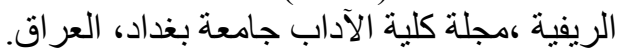

Website,https://.mandumah.com/RetrievedApril.

2018,10:51AM

الحوامدة، مها محمد محمود وابر اهيم سليمان الطاهات الزئي

(2017). دور المرأة الريفية في التتمية الزراعية الطية

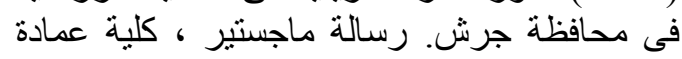

البحث العلمى والدراسات العليا، جامعة جرش،

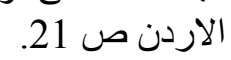

بناءاً على النتائج التى أسفر عنها البحث فإنها يمكن التوصية:-

1- يجب على الهيئة العامة لتعليم الكبار ومحو الامية

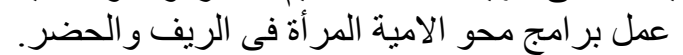

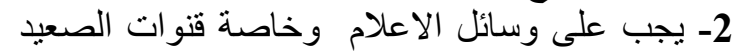

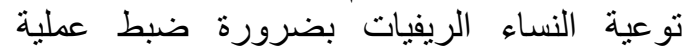

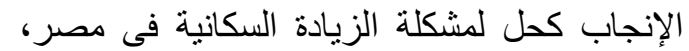

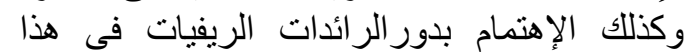

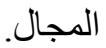

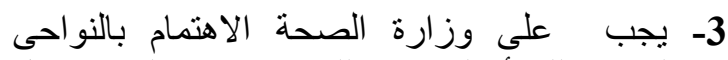

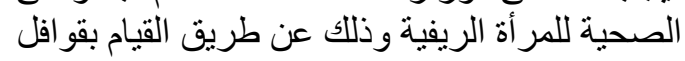
طبية فى القرى.

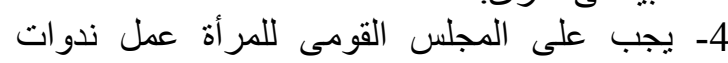

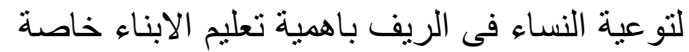
الاناث ، وكذنلك تو عيتهن بحقو قهن الاقتصادية.

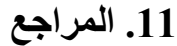

أولاً: المر اجع بالغة العربية

حجازي، هدى محمود حسن (2008). و واقع مشاركة المر أة 
Website, https://.mandumah.com/ Retrieved April.2018,1:32PM,

Website,https://.mandumah.com/ Retrieved April.2018,10: 51AM

\section{ثانياً:المراجع الاجنبية}

Ababakr S. H. and Akbay C. (2018). The obstacles of rural women participation in agricultural development in Erbil province of Iraq. Asian J. of Agric. Ext., Econ. Sociol., (22), (1)

http://www.sciencedomain.org/abstract/22672, Website, Retrieved August.2018,10: 30AM

Britt,Inga(1997). Improving the situation of women in rural society, Committee on Agriculture and Rural Development

Website,https://assembly.coe.int/Retrieved August.2018,10: 35AM

Butt T. M., Hassan Z. Y. and Khalid M. Sher Muhammad(2010). role of rural women in agricultural development and their constraints, J.Agric. and Soc. Sci., 6 No(.3):

website,https://www.fspublishers.org/publ ished_papers/1471.pdf, Retrieved July. 2018, 11: 10AM

FAO (2017). Challenges and opportunities in achieving gender equality and the empowerment of rural women and girls

Website,https://www.peacewomen.org/sit es/.../EP2\%20\%20Nino\%20Gamisonia.pd f, Retrieved August.2018,10: 28AM

Kongolo M.I. and Bamgose O.O.(2002). Participation of rural women in development: A Case Study of Tsheseng, Thintwa, and Makhalaneng Villages, South Africa. J. Int'1 Women's Studies, (4), (1):

Website, https://vc.bridgew.edu/jiws/vol4/ iss 1/6/,Retrieved August.2018,10:35AM

Miranda G. Vasques (2018). Women's Labor Force Participation in a Developing Society: The Case of Brazil, The University of Chicago Press, Website https://www.jstor.org/stable/317309, Retrieved July.2018,1: 2PM
Website,https://.mandumah.com/Retrieved April.2018,4:51PM

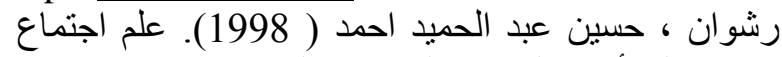
المرأة ، المكتب الجامعى الحديث ، الحيد الاسكندريةـ

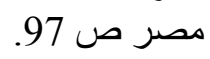

سالم ، امل مسعود محمود 97 (2009). محددات تمكين المرأة

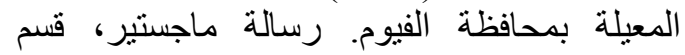
الاقتصاد الزراعى، كلية الزراعة، جامعة الفيوم، ماجئ،

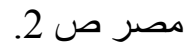

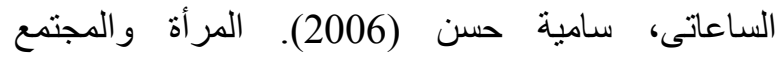
المعاصر، الهيئة المصرية العامة للكتاب، القاهرة.

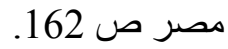
سلام، عازه محمد أحمد.(1995). بعض مض معوقات مشاركة المرأة الريفية فى تتمية مجتمعها ودور المؤسسات

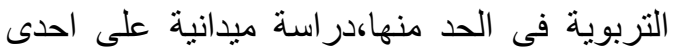

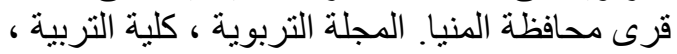

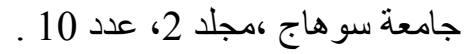

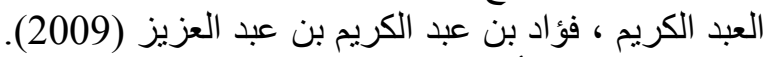

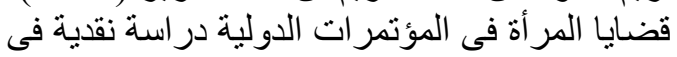

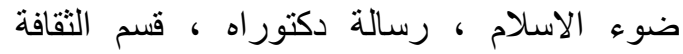
الاسلامية ، كلية الشريغة ،جامعة الامام محمد بن الاهن

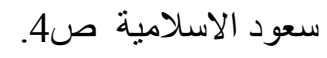

Website,https://dorar.net/article/224 Retrieved April.2018,4:55PM

عبدالنبي، سالم إبر اهيم و احمد سعيد محمد فؤاد (1999).

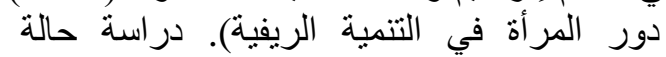

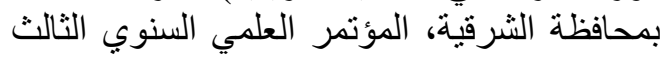

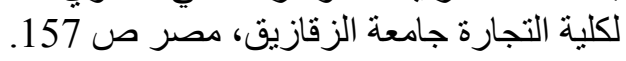

Website,https://.mandumah.com/RetrievedApril. 2018,10: 55AM

على، منال عبد المجيد ابو المجد (1993). معوقات الرئل

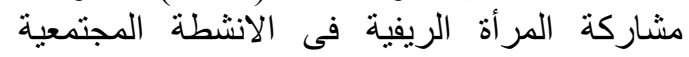

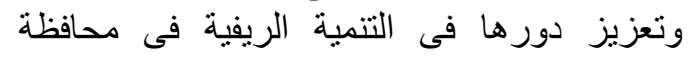

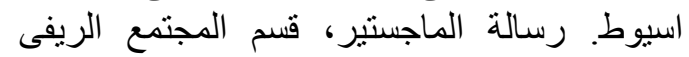
و الارشاد الزراعى ،كلية الزراعة، جامعة الئي الريوط. مصر ص الارثناد الز 3.

مبارك، هدى محمد عبداله وسلمى الخضيرى (1992).

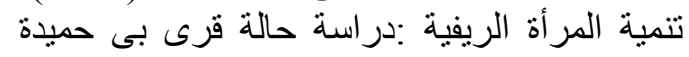

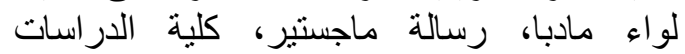
العليا،الجامعة الاردنيةـ الاردن صالة صادئ، 2.

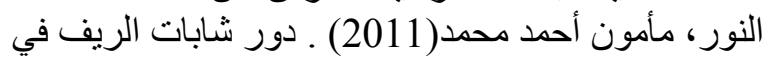

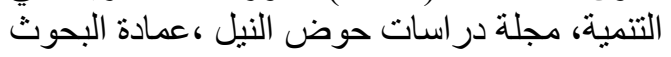
و التنمية و التطوير، جامعة النيلين، مجلد7، العددات البحد

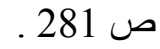

